\title{
QUANTIFYING THE RELATIONSHIP BETWEEN MICROBIAL ATTACHMENT AND MINERAL SURFACE DYNAMICS USING VERTICAL SCANNING INTERFEROMETRY (VSI)
}

\author{
K. J. DAVIS*† and A. LÜTTGE****
}

\begin{abstract}
A major challenge of biogeochemistry is to resolve the precise manner by which microbial activity influences mineral-surface reactions. Although a prerequisite for biological activity at a surface is substrate recognition and attachment, probing the nature of this biological-geological interface is inherently difficult. While atomic force microscopy (AFM) is a powerful high-resolution imaging technique capable of quantifying mineral-surface and microbial cell structure, it suffers from the invasive nature of tip-sample interactions and a limited field of view. A noninvasive imaging technique is needed that can detect the microbe at the surface and quantify any resulting changes in mineral-surface topography, while maintaining both a high spatial resolution and a large field of view. Vertical scanning interferometry (VSI) meets these requirements and enables the measurement of both local dissolution (etch pits) and global dissolution rates (surface normal retreat). Here we use AFM and VSI as complementary techniques to evaluate the influence of mineral-surface dynamics on the surface colonization of carbonate surfaces by Shewanella oneidensis MR-1. It was found that 1) surface colonization occurred more slowly on actively dissolving calcite surfaces than on the less dynamic dolomite and magnesite surfaces; 2) cell attachment reduced calcite dissolution rates by more than 40 percent relative to cell-free controls; 3) surface microtopographical features such as etch pits provide high-energy sites that favor microbial attachment. These results indicate the existence of a complex relationship between microbial surface colonization and mineral-surface dynamics that deserves additional study. Further, this study demonstrates that VSI is an effective method for quantifying mineral-reaction rates in the context of microbial attachment. Direct comparisons with atomic force microscope (AFM) measurements also established VSI as a capable technique for making ex situ measurements of cell and biofilm dimensions on the surface. Accordingly, VSI should be considered a valuable complement to those powerful tools already available to the geomicrobiologist for quantification of processes occurring at the microbe-mineral interface.
\end{abstract}

INTRODUCTION

Importance of Microbial Attachment in Biogeochemical and Engineered Systems

While microorganisms are routinely maintained and studied in the laboratory as liquid cultures, it is well established that the majority of bacteria in natural and engineered systems exist attached to surfaces (Korber and others, 1995; Fletcher, 1996; Mills and Powelson, 1996; Fortin and others, 1997; Little and others, 1997; Fletcher and Murphy, 2001). From the initial stages of surface colonization through the development of mature biofilms and microbial mats, the presence of microbes on surfaces has profound impacts on both the organisms themselves as well as the substratum. Attached bacteria reside and multiply within microenvironments that confer added survival benefits to the biota while producing specialized conditions that affect industrial and biogeochemical processes at the substrate interface. Often the simple presence of biofilms on engineered surfaces interrupts critical industrial processes. This biofouling causes such disparate problems as reduced heat transfer on heat exchangers, increased fluid frictional resistance on pipelines and ship hulls, and

\footnotetext{
*Department of Earth Science, Rice University, 6100 Main Street, Houston, Texas 77005, U.S.A. U.S.A.

**Center for Biological and Environmental Nanotechnology, Rice University, Houston, Texas 77005 ,

${ }^{+}$Corresponding author: K. J. Davis, kjdavis@rice.edu
} 
infections on implant surfaces (Characklis, 1990; Flemming and Schaule, 1996; Geesey and Bryers, 2000). The ability of attached microorganisms to alter the physical and chemical environment at inorganic interfaces further disrupts engineered processes by degrading the material itself. Biocorrosion or microbiologically influenced corrosion (MIC) occurs when microbes initiate, facilitate, or accelerate the corrosion reaction, enhancing the damage to the metal (Little and others, 1990; Hamilton, 1995; Videla, 1996; Wagner and others, 1996; Geesey and others, 2000). The widespread economic implications of these collective processes have driven intense interdisciplinary research in the biological, medical, materials, and engineering sciences over the past 30 years, with the goal of achieving a basic understanding of the factors that govern cell attachment and elucidating the mechanisms by which surface colonization affects reactions occurring at inorganic surfaces (Lens and others, 2003).

Over this same period, there has evolved an increasing realization in the earth sciences that many critical geochemical mineral-surface processes are mediated by microbial activity (Banfield and others, 1998; Ehrlich, 1998; Ehrlich, 1999). While microorganisms can modify mineral reaction rates by altering the chemical environment, physical attachment to the mineral-substrate may be of the most direct consequence to surface-controlled processes. Microbes attach to mineral surfaces for a variety of reasons. First, many nutrients tend to concentrate at surfaces (ZoBell, 1943). Surface-associated bacteria are able to utilize these nutrients for growth allowing them to multiply at the solid-water interface under conditions in which they are unable to multiply in the bulk aqueous phase (Marshall, 1996). Secondly, some minerals themselves serve as energy sources for microbial metabolism. The best-known example of this is the coupling of organic carbon oxidation to the dissimilatory reduction of $\mathrm{Fe}$ and Mn (Lovely and Phillips, 1988; Nealson and Myers, 1992). Microbial attachment to metal oxide surfaces is often requisite for taking advantage of this metabolic pathway (Arnold and others, 1988; DiChristina and Delong, 1994), although extracellular electron shuttle compounds, such as humics (Lovley and others, 1996; Lovley and Blunt-Harris, 1999) and quinones (Newman and Kolter, 2000; Rosso and others, 2003), also play a role. Additionally, microbes colonize surfaces as a general response to a range of environmental stresses where surface attachment offers protection and the opportunity for synergistic relationships with other cells (Dawson and others, 1981; Kjelleberg and Hermansson, 1984). Whatever the primary cause of microbial attachment, surface colonization generally results in degradation of the mineral surface and a considerable increase in the total reactive surface area. During this process, microbes produce acids, bases, and ligands that interact with the mineral surface, promoting mineral dissolution and the formation of secondary mineral phases (Bennett and others, 1996; Barker and others, 1997; Ehrlich, 1998). Where conditions in the natural environment favor microbial surface colonization, microbial processes can be expected to influence observed mineral dissolution rates.

\section{Critical Questions that Require Further Study}

Resolving the role of microbial surface colonization in mediating mineral dissolution rates is requisite for understanding the reactivities of biogeochemically-significant materials. However, basic gaps in our understanding of the mechanisms by which microorganisms mediate the evolution of natural surfaces have slowed the establishment of quantitative models describing mineral weathering rates in the context of microbial attachment. Some key questions that have yet to be answered in a comprehensive manner are:

1. How do the properties of the mineral surface influence bacterial attachment? In other words, what are the surface-structural controls on bacterial attachment?

The majority of experimental work has been carried out to discern the environmental and metabolic conditions that favor microbial attachment to various substrates 
(Grasso and others, 1996). However, little is known about the controls exerted by the microstructure of the surface on surface colonization. Engineering studies have correlated microbial attachment with the surface roughness of industrially significant materials (Scheuerman and others, 1998). Likewise, the degree to which environmental samples are etched has been shown to affect bacterial colonization (Bennett and Hiebert, 1992; Hiebert and Bennett, 1992; Bennett and others, 1996). However, microbial interactions with specific topographic features, especially submicron features, remain largely unresolved. While atomic force microscopy (AFM) has been used with considerable success to measure forces between bacteria and various substrates (Lower and others, 2000, 2001a, 2001b), this technique has only recently been applied to discern attachment forces between bacteria and certain topographic features (Boyd and others, 2002). It is critical that such studies begin to yield a mechanistic understanding of the interaction between microbes and microtopography, so that the precise role that surface microstructure plays in directing bacterial colonization may be resolved.

2. What is the mechanism by which bacterial attachment modifies mineral dissolution rates? What are the consequences of bacterial attachment on the microtopographic features known to control abiotic dissolution rates?

Just as important as understanding microtopographical controls on surface colonization, is determining the manner by which microbial attachment, in turn, modifies the structure and development of the surface. This is especially significant given the known dependence of surface-controlled mineral reaction rates on the microstructure of the surface. Numerous AFM studies have demonstrated the dependence of layer-bylayer growth or dissolution on the formation of growth spirals and etch pits at surface defects (Gratz and others, 1993; Liang and others, 1996; Jordan and Rammensee, 1998; Pina and others, 1998; Teng and others, 1998; Davis and others, 2000; Higgins and others, 2000; Teng and others, 2000; Risthaus and others, 2001; Davis and others, 2004). The more recent use of vertical scanning interferometry (VSI) has successfully correlated observations of etch pit formation with surface normal retreat and global dissolution rates (Lüttge and others, 1999; Arvidson and others, 2003, 2004). A conceptual model for mineral dissolution has been inferred from these interferometric measurements of surface topography (Lasaga and Lüttge, 2001, 2003). The resultant comprehensive dissolution rate theory successfully integrates individual surface reactions into an overall rate. These studies provide a conceptual abiotic framework by which the biological influence on mineral-dissolution rates may be compared.

3. How does the dynamic nature of the actively dissolving mineral surface affect bacterial attachment. For instance, can the dissolving surface retreat beneath the attached bacteria, thereby enhancing the probability of detachment? Additionally, what is the relationship between mineral solubility and the role of microbial surface colonization in weathering reactions?

To date, most investigations have studied microbial attachment to either inert surfaces or slowly dissolving surfaces. The precise role of mineral solubility, and hence dissolution rate, in determining the extent and rate of microbial surface colonization is largely unknown.

\section{Quantifying Microbe-Mineral Interactions - A Challenge}

Determining experimental answers to these questions has been slowed by difficulties inherent to measuring processes occurring at the microbe-mineral interface. Probing the nature of microbe-surface interactions in a quantifiable manner has principally been achieved through the use of atomic force microscopy (AFM). The power of this method lies in its ability to image live cells in situ and its exquisite spatial resolution of changes in microtopography as well as of microbial cell structure. However, this technique suffers from the invasive nature of tip-sample interactions and 
its limited field of view. For instance, direct measurement of global surface dissolution rates is largely unattainable using AFM. A complementary noninvasive imaging technique is needed that can both detect the microbe at the surface and quantify any resulting changes in mineral-surface topography, while maintaining both a high spatial resolution and a large field of view. Vertical scanning interferometry (VSI) meets these requirements and enables the measurement of both local dissolution (etch pits) and global dissolution rates (surface normal retreat) (Lüttge and others, 1999, 2003).

VERTICAL SCANNING INTERFEROMETRY (VSI)

Interferometry is an optical technique that is commonly used to measure surface topography with very high precision. Interferometers produce surface height maps by splitting a beam of light exiting a single source into two separate beams. One beam is reflected from the sample surface while the other is reflected from a reference mirror. When the two beams are recombined, interference phenomena produce an interferogram consisting of fringes that reflect the topography of the sample surface. Modern interferometers use a charge coupled device (CCD) detector to register and feed the interferogram to a computer where phase-mapping programs produce a topographic image of the surface.

Vertical scanning interferometry (VSI) is a type of interferometry that is optimized for the wide dynamic range needed to image rough surfaces. It typically uses a white light illumination source, which allows for large vertical scans (up to $100 \mu \mathrm{m}$ with better than $2 \mathrm{~nm}$ resolution). Since the coherence length is short due to the wide spectral bandwidth of the white-light source, good contrast fringes are only obtained when the two path lengths of the interferometer are closely matched in length. Therefore, the interferometer is aligned so that the interference intensity distribution along the vertical scanning direction has its peak (best contrast fringes) at the best focus position. While many algorithms are employed to analyze white light interferograms, all of them generally detect the coherence peak.

Although VSI is primarily used for non-destructive testing of semiconductors, it has also been used with considerable success to measure mineral-surface kinetics (Lüttge and others, 1999, 2003; Arvidson and others, 2003, 2004). This success stems from the speed, precision and versatility by which VSI produces quantitative topographic maps of the mineral surface. Images made at 50x magnification using white-light illumination provide a lateral resolution of $\sim 0.5 \mu \mathrm{m}$, while maintaining a vertical resolution on the order of 1 to $2 \mathrm{~nm}$. The scan size at this magnification is $165 \mathrm{x}$ $125 \mu \mathrm{m}$, a little larger than the maximum AFM scan size of $130 \times 130 \mu \mathrm{m}$. However, interference objectives can be easily switched via a turret providing, for instance, 10x magnification with a field of view of $845 \times 630 \mu \mathrm{m}$. When larger scan areas are needed, a "stitching" procedure can be employed in which a number of overlapping measurements are combined into one surface profile using an automated positioning stage and sub-pixel registration techniques. VSI employs a $2 \mu \mathrm{m} / \mathrm{s}$ vertical scan rate allowing for extremely fast data acquisition. For instance, a surface area of $1 \mathrm{~mm}^{2}$ with $20 \mu \mathrm{m}$ of surface relief can be quantified in less than ten seconds.

Since interferometry measures relative surface height, absolute changes in mineralsurface topography must be measured relative to a reference surface. This is achieved by placing an inert mask on the surface. By measuring the average height difference between the reacted and unreacted surfaces, an absolute value of surface normal retreat may be determined. Thus, during dissolution, changes in average height $\Delta \bar{h}$ made at time intervals $\Delta t$ yields a surface normal retreat velocity, $v_{[h k]}$ :

$$
\frac{\Delta \bar{h}}{\Delta t}=v_{[h k l]} .
$$


Dividing this velocity by the molar volume $\bar{V}\left(\mathrm{~cm}^{3} / \mathrm{mol}\right)$ gives a global dissolution rate in the familiar units of moles per unit area per unit time:

$$
r=\nu_{[h l]} \bar{V}^{-1} \text {. }
$$

This approach allows a simple and straightforward calculation of surface-area retreat or advance rates from measurements of average surface heights $(\Delta \bar{h})$ (Lüttge and others, 1999). In addition to these global dissolution rates, local dissolution rates at etch pits can be quantified by monitoring changes in the volume and density of etch pits across the surface over time.

The key to achieving accurate measurements of mineral-reaction rates using this masking technique is the large vertical scan range and field of view available using VSI. For instance, AFM can in principal be used to measure surface retreat rates relative to a masked reference surface. However, the relatively small vertical scan range $(\sim 7 \mu \mathrm{m})$ and lateral scan size of AFM makes it impossible to achieve accurate measurements of surface reaction rates. Even using VSI it is clear that the 10x objective provides a much more accurate measurement of surface normal retreat than is determined using the $50 \mathrm{x}$ objective. This is because the limited field of view provided by the 50x objective is more sensitive to influences from local dissolution features and reaction artifacts associated with the mask edge.

THE APPLICATION OF VSI TO THE QUANTIFICATION OF MINERAL SURFACE DYNAMICS IN THE CONTEXT OF MICROBIAL ATTACHMENT

While VSI is becoming a standard technique for the quantification of mineralsurface reactions in inorganic systems, its application to microbial systems has not been fully evaluated. Only one previous study has attempted to use VSI to investigate microbe-mineral interactions (Lüttge and Conrad, 2004). In this work, surface colonization by Shewanella oneidensis MR-1 was observed to prevent the opening of etch pits on the calcite surface, despite undersaturated solution conditions. The authors hypothesized that this dissolution mechanism was dependent upon both the biomass to surface area ratio and the rate at which the etch pits opened. Unfortunately, these experiments used a high cell titer and small reaction volume, thereby precluding any possibility of large-scale calcite dissolution from occurring. Yet, this study raises an interesting question: what is the relationship between microbial surface colonization and the dynamics of the surface (that is dissolution rate)? If microbial attachment influences the dissolution of the surface, can surface dissolution, in turn, affect microbial attachment?

Here we further investigate the relationship between microbial surface colonization and mineral-surface dynamics by examining three key interactions:

1. The rate of cell attachment as a function of carbonate dissolution rate

2. Calcite dissolution rate in the presence of microbial cells versus a cell-free control

3. The role of mineral-surface topography in determining cell attachment

A second goal of this paper is to further evaluate the applicability of VSI to the quantitative study of mineral-surface reactions in the context of microbial attachment. To this end, VSI measurements of cell and biofilm dimensions will be directly compared to those obtained using the more commonly used quantitative imaging technique, AFM.

EXPERIMENTAL METHODS

\section{Mineral-Surface Selection and Preparation}

The carbonate mineral system (calcite, dolomite, magnesite) was selected as the ideal set of substrates for testing the dynamic relationship between microbial attach- 
ment and mineral dissolution in a laboratory setting. Calcite crystals dissolve readily in aqueous solutions while dolomite and magnesite surfaces are relatively inert over the short experimental durations employed in this paper. However, these three minerals present similar crystal chemistries to the cells in solution and are not part of any known microbial respiratory pathway. Cleavage surfaces of calcite, magnesite and dolomite were prepared using a razor blade and mounted on glass coverslips using sealing wax. The glass coverslips were in turn mounted on stainless steel coupons similar to those commonly used for AFM analysis. The purpose of the glass coverslip was to minimize metal exposure to the test solutions during the course of the experiments. Additional dolomite and barite (001) cleavage surfaces were prepared and mounted in a similar fashion to be used in pre-etching experiments. Here, barite was chosen for its tendency to form elongated polygonal etch figures with a symmetry that is distinct from those that form on the dolomite surface. The dolomite surfaces were pre-etched in $1 \mathrm{M} \mathrm{HCl}$ for 30 minutes, while the barite surface was etched in deionized water (DIW) for approximately ten days prior to exposure to the experimental solutions. At least two reference masks were applied to each crystal surface prior to reaction and allowed to cure for 24 hours. The masks used in this study were made using Permatex (www. permatex.com), a commercially-available high-temperature silicone gasket making compound. This type of mask has previously been used in abiotic calcite dissolution experiments where it was found to have no measureable effect on solution chemistry or observed rates (Arvidson and others, 2003; Lüttge and Conrad, 2004).

\section{Shewanella Culture Preparation and Controls}

We chose Shewanella oneidensis MR-1 (formerly Shewanella putrefaciens strain MR-1) for our attachment studies due to its propensity to form biofilms, ubiquity in the natural environment, and its use as a model microbe for bioremediation studies (Tiedje, 2002). In addition, S. oneidensis exhibits both motile (flagellated) and nonmotile phases, and shares cell surface similarities with Pseudomonas, the focus of many adhesion studies (Bakke and others, 1990; Prince, 1996).

Shewanella oneidensis MR-1 cultures were obtained from Kenneth Nealson's lab (University of Southern California) and aerobically cultured in a $\mathrm{pH}$ 7.4, low-nutrient medium, prepared to 1L using: $200 \mathrm{mg}$ yeast extract, $100 \mathrm{mg}$ peptone, $10 \mathrm{~mL} 1 \mathrm{M}$ HEPES, $10 \mathrm{~mL} 0.2 \mathrm{M}$ bicarbonate and $20 \mathrm{~mL} 1 \mathrm{M}$ lactate. The culture was allowed to enter stationary phase as monitored by spectrophotometric absorbance measurements, with a final A600 reading of 0.15 , corresponding to a cell titer of $3 \times 10^{8}$ cells $/ \mathrm{mL}$. Two portions of this culture were used as control solutions. The first control was a cell-free extract that was prepared through centrifugation of the culture at 9000 rpm for $30 \mathrm{~min}$. The supernatant was decanted from the pellet and the centrifugation step repeated twice more. Following this procedure, the spectrophotometric absorbance A600 of the solution fell to 0. A second dead-cell control was prepared by heat-killing the cells through incubation above $45^{\circ} \mathrm{C}$ and below $55^{\circ} \mathrm{C}$ for 2.5 hours and then allowing the culture to cool and repeating the cycle two more times. The measured spectroscopic absorbance A600 of the solution fell to 0.12 during this procedure. Viability of the dead-cell control was assessed by counting the number of colony-forming units (cfu) per volume plated on Luria-Bertani (LB) agar plates. It was determined that less than 1 bacterial cell per $\mathrm{mL}$ of culture was microbiologically viable.

\section{Reaction Conditions}

Crystals were reacted in 100x15mm Petri dishes containing $50 \mathrm{~mL}$ of cell culture or control solution. The Petri dishes were placed on a platform shaker set to $25 \mathrm{rpm}$ for the duration of the experiment. The lids of the dishes were left slightly ajar so that aerobic conditions were maintained throughout the experiment. For each experi- 
TABLE 1

Average Measured Attached Cell Densities (Cells/100 $\mathrm{mm}^{2}$ )

\begin{tabular}{|c|c|c|c|}
\hline & Calcite & Dolomite & Magnesite \\
\hline 8 Hours & 2.11 & 4.26 & 3.45 \\
\hline 35 Hours & 3.12 & 6.24 & 9.89 \\
\hline
\end{tabular}

ment, multiple crystals of each species were reacted in each test solution. Further, each crystal had multiple masked regions for maximum internal controls. When comparing different mineral surfaces in the same test solution, all crystal species were placed in the same Petri dish and therefore exposed to the same experimental conditions. Due to the high number of complexation sites present on the microbe surfaces and organic species in solution, it was not possible to monitor calcium or carbonate species in solution during the course of the experiment. Following the 35 hour reaction period, the solutions were decanted from the Petri dishes containing the crystals and remeasured for $\mathrm{pH}$ and absorbance. The $\mathrm{pH}$ of the live Shewanella culture remained at 7.4, while the cell-free and dead-cell controls rose slightly to 7.5. The measured absorbance of the live Shewanella cultures fell to 0.11 during the experiment, most likely as a result of attachment to the crystals surfaces and the bottom of the Petri dish. The absorbance of the cell-free and dead-cell controls were measured to be the same as at the beginning of the experiments. The crystals were washed in a standardized fashion necessary for accurate cell density measurements. Each stainless steel coupon (containing the test crystal) was lodged vertically in a $15 \mathrm{~mL}$ centrifuge tube using a pair of tweezers. The tube was gently filled with DIW, capped, rotated end-over-end and emptied. This procedure was repeated two more times for each crystal prior to imaging.

\section{VSI And AFM Imaging and Measurements}

A commercially-available MicroXAM MP-8 (ADE Phase-shift, Tucson, AZ) vertical scanning interferometer (VSI), equipped with 10x and 50x Nikon Mirau objectives, was used to image the crystal surfaces. The $10 \mathrm{x}$ interferometric objective yields a $845 \mathrm{x}$ $630 \mu \mathrm{m}$ field of view, while the 50x objective allows for scan sizes of $165 \times 124 \mu \mathrm{m}$. There are two basic types of images that can be generated from data sets acquired using VSI. The standard data file is a 2-dimensional (2D) topographic image similar to height images obtained using AFM, where topographic information is conveyed according to a color scale. In these images, bright colors typically indicate higher surface features on the image. The second image type used in this study is a 3-dimensional (3D) solid-model representation of the topographic information contained in the VSI data file.

Measurements of cell densities on the carbonate surfaces were made by counting the number of cells per area in randomly selected images or portions of images. Averages of at least 20 separate counts are reported in tables 1 and 2. When available, AFM observations were found to confirm the VSI cell density measurements. Global dissolution rates were measured after 35 hours for at least two masks per mineral species and for at least two crystals for each mineral species. At least ten transects were measured along each mask, paying careful attention to taking transects along a single continuous terrace to avoid error from natural surface steps.

A Multimode Nanoscope III AFM (Digital Instruments, Santa Barbara, CA, USA) was used to make the ex situ (in air) observations of mineral surfaces used in this study. 
TABLE 2

Measured Attached Cell Densities on Pristine and Pre-Etched Surfaces after 4 Hours (Cells $\left./ 100 \mu \mathrm{m}^{2}\right)$

\begin{tabular}{|c|c|c|}
\hline & Dolomite & Barite \\
\hline Pristine Surfaces & 1.10 & 2.00 \\
\hline Pre-Etched Surfaces & 5.96 & 5.06 \\
\hline
\end{tabular}

This instrument was equipped with a J piezoelectric scanner with a maximum range of $130 \times 130 \mu \mathrm{m}$. While Tapping Mode is often the preferred technique for imaging biological materials, the Shewanella cells were found to be attached strongly enough to the crystal surface to allow for Contact Mode imaging using minimal contact forces. It was found that this imaging technique provided the best resolution of both surface topography and attached cells.

RESULTS AND DISCUSSION

\section{Surface Colonization on Carbonate Surfaces}

$S$. oneidensis surface colonization was monitored at time intervals using the interferometer. Each carbonate crystal was observed immediately after it had been washed using the standardized procedure described in the methods section. Timeseries analyses demonstrated that the carbonate surfaces underwent continuous surface colonization during the course of the 35 hour exposure period studied (fig. 1). The early stages of surface colonization were characterized by the formation of a honeycomb-shaped network of attached cells surrounding cell-free portions of the crystal surface (fig. 1A). During this period, attached cell density was found to be highest on the interior portions of the crystals and lowest near the crystal edges. While attachment rates varied to some degree between crystals and locations on the same

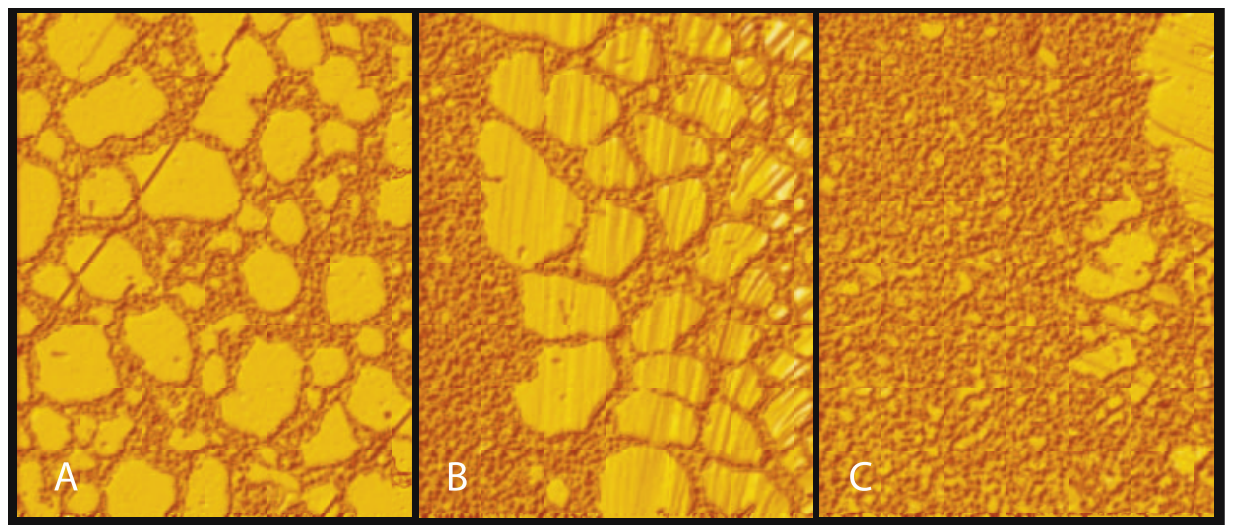

Fig. 1. 3D plots of VSI data sets showing progressive surface colonization by Shewanella on dolomite over 35 hours. (A) honeycomb morphology after 9 hours; (B) beginning of monolayer surface coverage after 18 hours of exposure; (C) after 25 hours, most of the central regions of the crystal surface were covered by a continuous monolayer of cells. (All images were captured using a 50x interferometric objective yielding image sizes of $165 \times 125 \mu \mathrm{m}$.) 


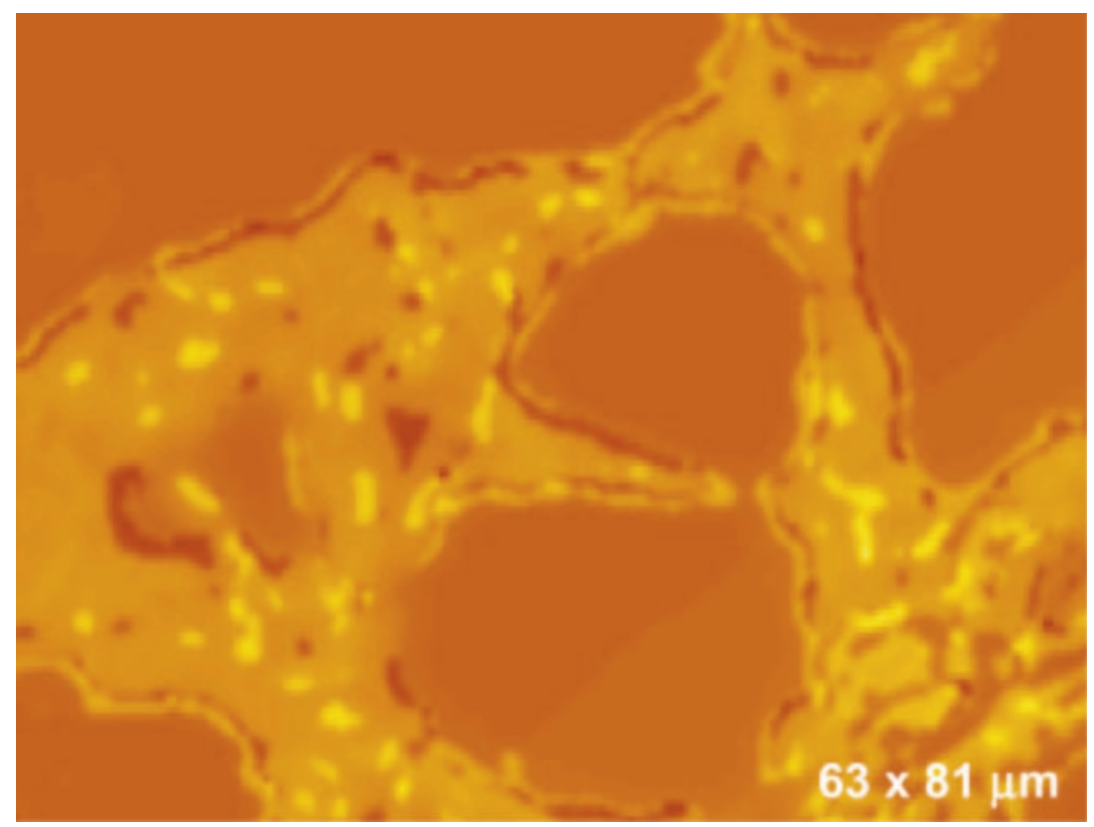

Fig. 2. 2D VSI image of Shewanella surface colonization on a magnesite surface after 9 hours. This early biofilm consists of taller (bright-yellow) cells and associated lower (dark yellow) organic material.

crystal, most of the crystal surfaces were nearly completely covered by a monolayer biofilm after the 35 hour observational period (fig. 1C). It was apparent from the topographic images acquired using VSI that the attached cells were surrounded by organic material, possibly a conditioning film or the result of early extracellular polysaccharide (EPS) production (fig. 2). The physical dimensions of this associated organic material as well as of the cells themselves could be directly determined from the VSI images (fig. 3). The cells were found to range from 2 to 3 microns in length and from 400 to $650 \mathrm{~nm}$ in diameter. The associated organic material was consistently measured to rise 200 to $250 \mathrm{~nm}$ above the surface of the crystal. It was found that much of the organic material associated with the attached cells could be removed if the crystal surfaces were exposed to a direct stream of DIW from a wash bottle soon after removal from the bacterial cultures. Subsequent VSI imaging revealed clearly visible entrenched cells arranged in the same patterns as previously observed, but less obscured by associated organic material (figs. 4 and 5). However, this washing step also caused some of the attached cells on the surface to lyse, as was evidenced by measured cell dimensions (cell diameters on the order of $100 \mathrm{~nm}$ ) that were significantly smaller than undamaged cells.

In general, cells were found to attach to the carbonate substrates in essentially a random orientation. The lack of preferred alignment on the surface provided no evidence that mineral-surface microtopography played a definitive role in $S h$ ewanella surface colonization. However, as figure 6 demonstrates, some cells were observed to align along suitable topographic features. Nonetheless, it must be concluded that under the experimental conditions studied, Shewanella surface colonization was not limited by the availability of energetically favorable attachment sites. 


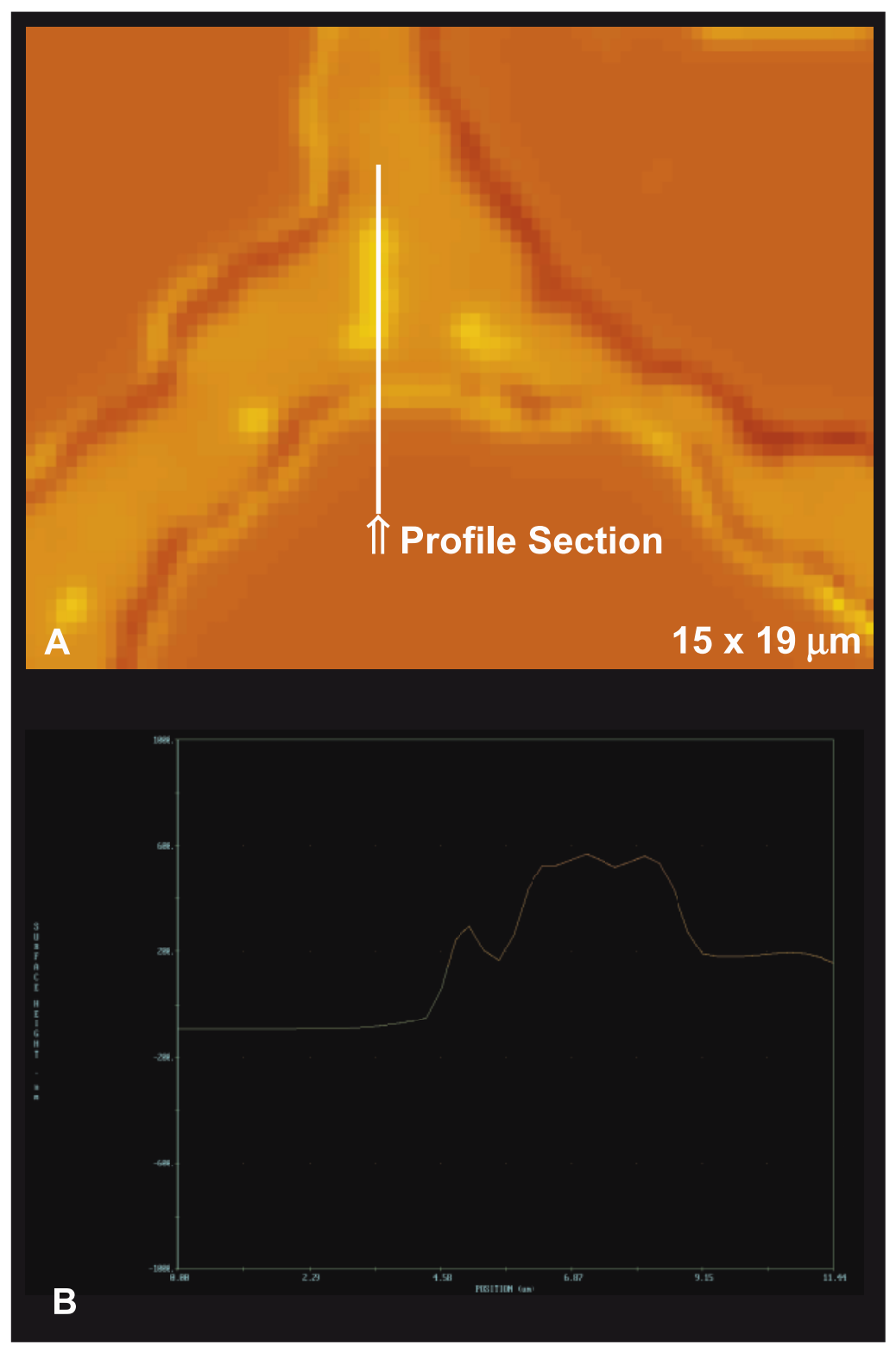

Fig. 3. Cross-section measurements of a single Shewanella cell on a dolomite surface and its associated organic material. Here, the cell is $650 \mathrm{~nm}$ in diameter, 3 microns long, and the associated organic material rises $200 \mathrm{~nm}$ above the crystal surface.

\section{Comparison of VSI and AFM Imaging Techniques and Measurements}

Many of the same crystal surfaces that had been exposed to the Shewanella cultures were imaged on the AFM immediately after analysis on the interferometer. While Tapping Mode (Acoustic AC Mode) AFM can be used for in situ imaging of biological materials, ex situ (in air) Contact Mode imaging was found to yield the best resolution of both attached cells and underlying crystal microtopography. Additionally, these 


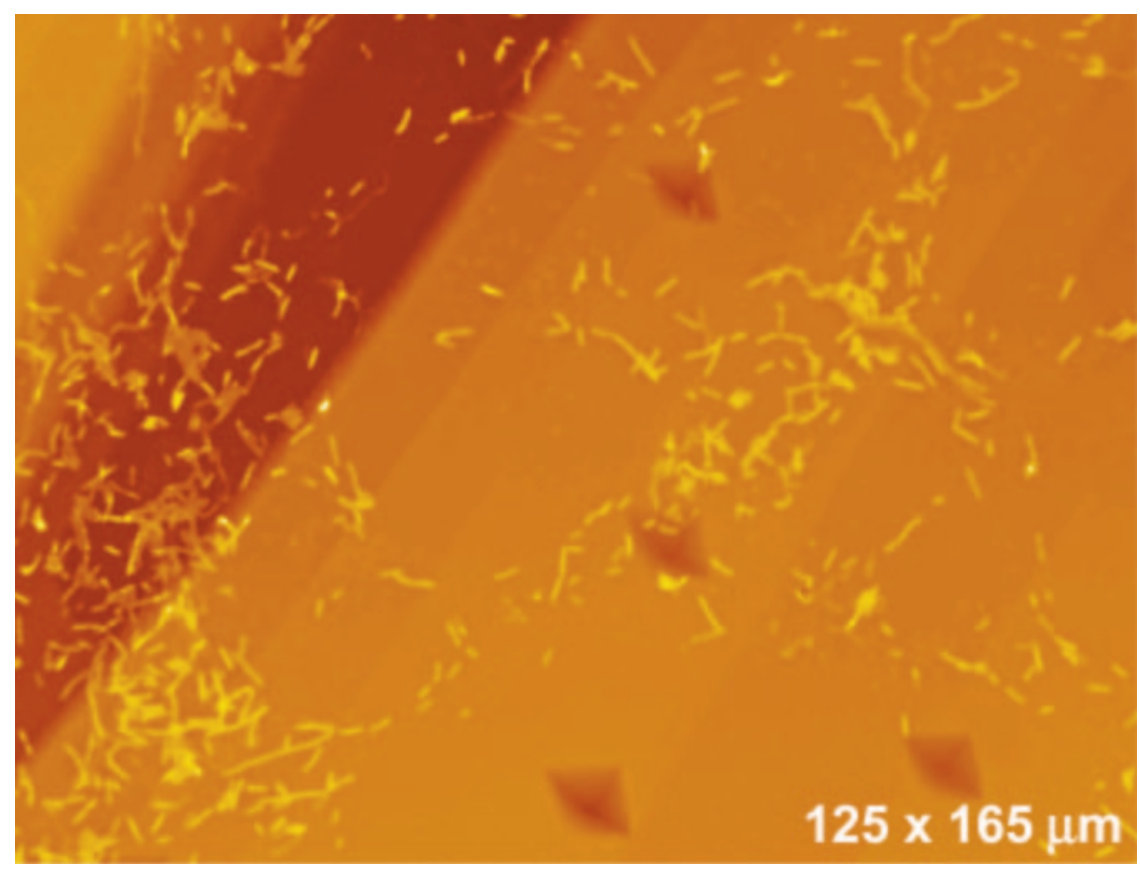

Fig. 4. 2D VSI image of entrenched cells on calcite following the removal of associated organic material. (9 hours exposure to Shewanella culture.)

imaging conditions were most similar to those employed using VSI, making possible direct comparisons between AFM and VSI measurements. For imaging ease, only those crystal surfaces that had most of the associated organic material washed away were imaged on the AFM.

While bacterial cell dimensions are near the lateral resolution limits of the $50 \mathrm{X}$ interferometric objective used in VSI, higher-resolution AFM imaging provided concise images of microbes at the mineral-surface (figs. 7 and $8 \mathrm{~A}$ ). In fact cell structures such as flagella are easily resolved using AFM (fig. 8B). However, despite the resolution difference between the two techniques, VSI measurements of cell diameter and length (fig. 9) were found to be very comparable to those measured using AFM. This is an interesting result given that the lower resolution of VSI causes the shape outline of the cells to appear somewhat diffuse. Fortunately, the optical nature of VSI that is responsible for such limitations in lateral resolution also confers certain advantages to VSI over AFM. The noninvasive nature of VSI imaging does not suffer from the tip-sample interactions inherent to AFM imaging that can cause bacterial cells to dislodge from the surface during imaging. Further, the large field of view and fast data acquisition allows VSI to quickly assess attached cell density over the entire crystal surface. Although not studied here, the large vertical scan range characteristic of VSI may even allow for the quantification of developing biofilm structures up to $100 \mu \mathrm{m}$ above the surface. These capabilities make VSI a strong complement to the in situ high-resolution imaging abilities of AFM. The coupling of these two techniques allows for mineral-surface reactions and cell-mineral interface processes to be quantified at multiple length-scales. 

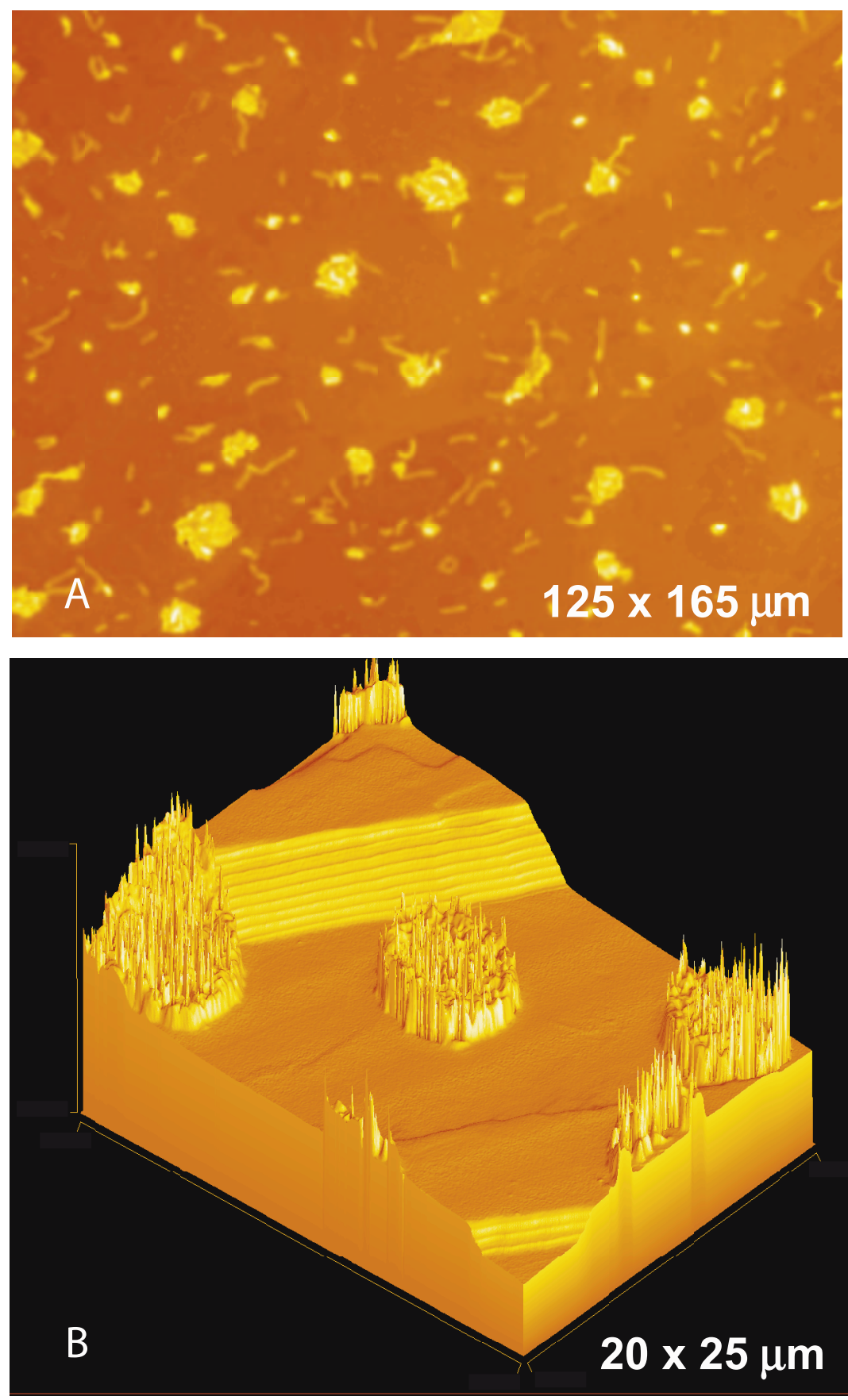

Fig. 5. The removal of associated organic material revealed the clear presence of Shewanella microcolonies on the calcite surface. The initial stages of surface colonization were often characterized by microcolony formation. (A) 2D VSI image; (B) 3D reconstruction of microcolonies in the context of natural surface topography. (8 hours of exposure to Shewanella cultures.) 


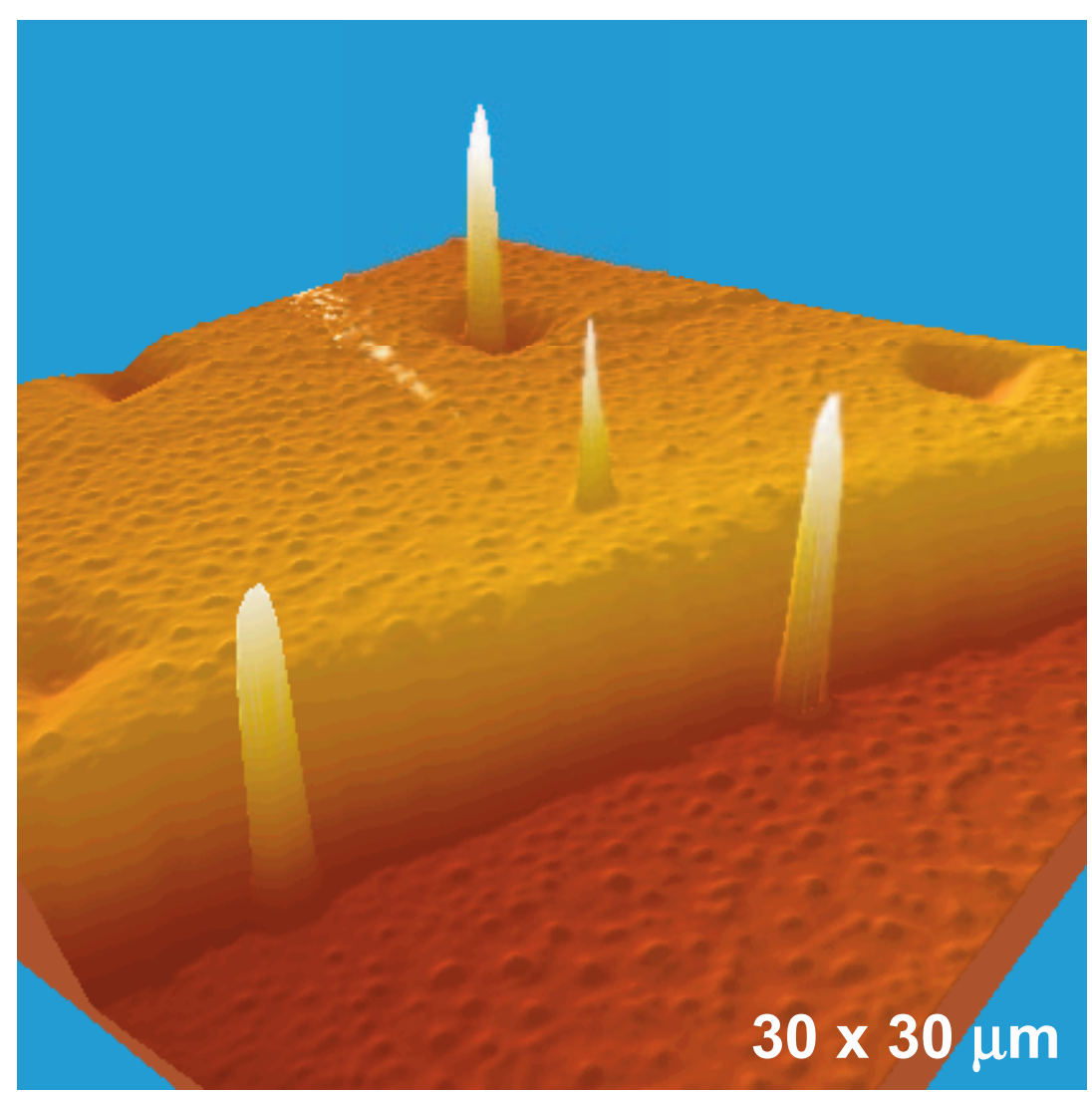

Fig. 6. The role of mineral-surface microtopography in determining cell attachment on calcite. This image is a 3D representation of a VSI data set that was generated using the SPIP 3.0 software package (www.imagemet.com). The bright-yellow peaks are bacterial cells. Two cells are attached lengthwise along a macrostep; one cell is attached to the center of an etch pit; one cell is attached to a flat terrace. The etch pits are between 75 and $142 \mathrm{~nm}$ deep. The macrostep is $230 \mathrm{~nm}$ tall. The microbe in the center of the etch pit is $560 \mathrm{~nm}$ tall and 3.5 microns in length. The microbe attached to the surface is $325 \mathrm{~nm}$ tall and 2.0 microns in length. The two cells attached lengthwise to the step are between 475 and $525 \mathrm{~nm}$ in height and 2.0 to 2.75 microns in length. This image indicates that while cell alignment may occur along energetically favorable attachment sites, the availability of such sites did not limit surface colonization.

\section{Role of Mineral-Surface Dynamics in Surface Colonization}

As expected, the solubility differences between the carbonate minerals used in this study resulted in significantly different dissolution rates as monitored by VSI. Etch pits were visible on the calcite surfaces within ten minutes of reaction with either the cell-free control solutions or the Shewanella cultures. In contrast, no dissolution was observed on the dolomite or magnesite surfaces during the 35 hour experiment. This difference in reactivity was most notable when comparing masked and unmasked regions of the crystal surfaces (figs. 10 and 11). Accordingly, the use of these different carbonate surfaces offered the opportunity to examine the role of mineral-surface dynamics in microbial surface colonization while still presenting relatively similar surface chemistries and crystal structures to the attaching cells.

Surface colonization rates on the various carbonate surfaces were determined by simply counting the numbers of attached cells per unit area on the crystal surfaces after 8 and 35 hours of exposure to the Shewanella cultures. The results of these surface cell 


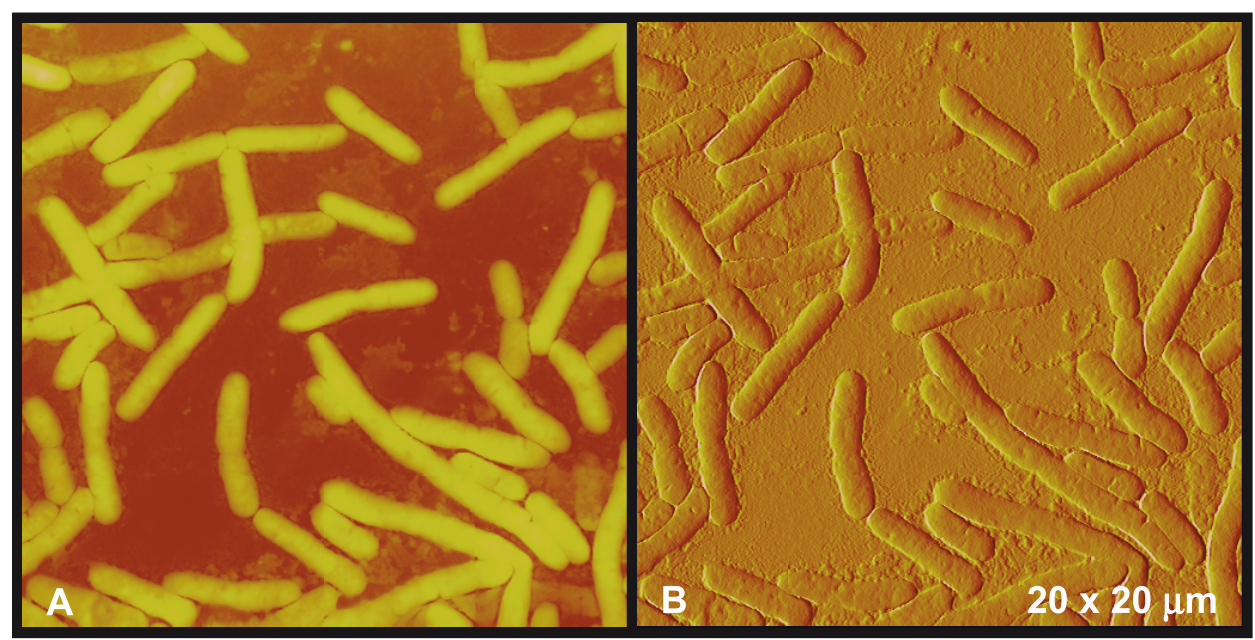

Fig. 7. FM images of Shewanella surface colonization on a dolomite surface after 35 hours. (A) height image; (B) deflection (amplitude) plot.

density measurements are given in table 1 and representative images are shown in figure 12. At both the 8 and 35 hour time points, the attached cell density on the calcite surfaces was found to be approximately half of those measured on the dolomite and magnesite surfaces. This finding indicates that cell attachment occurred more slowly on actively dissolving calcite surfaces than on the less dynamic dolomite and magnesite surfaces. Further, after the 35 hour experiments, it was clear that the majority of visible cells on the calcite surfaces were attached to the rims of large etch pits (fig. 13). This observation may further indicate that conditions for microbial attachment are less favorable near the centers of dissolution where the surface is most dynamic.

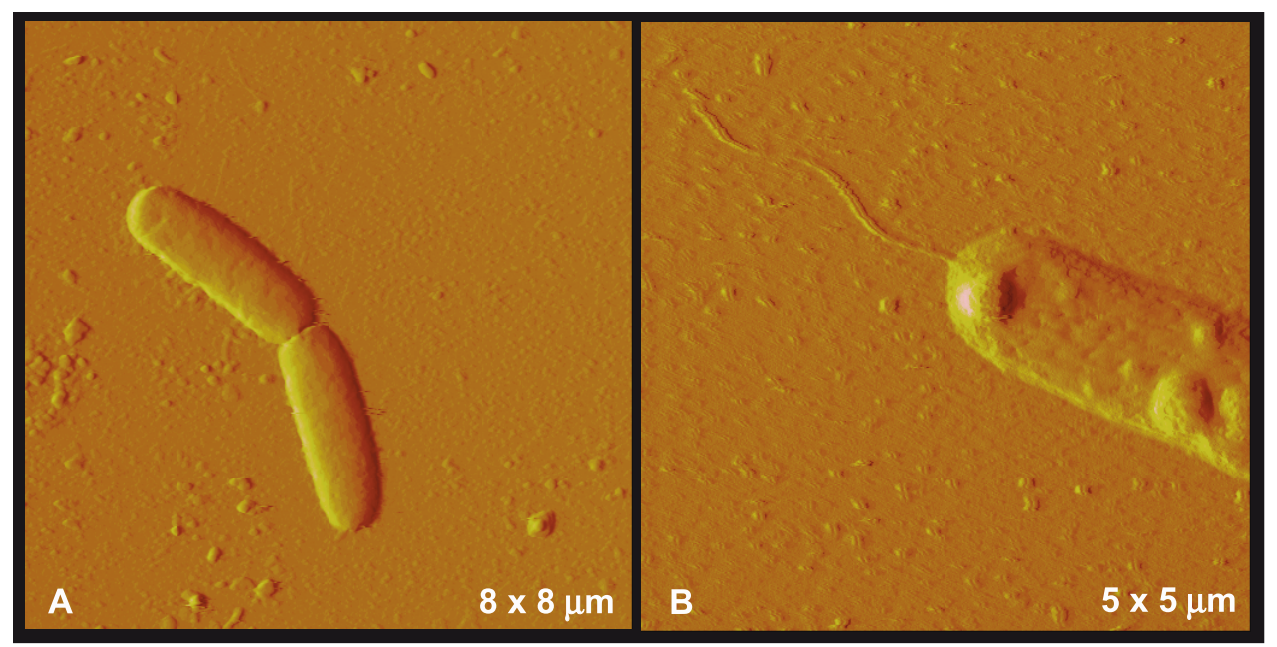

Fig. 8. High-resolution deflection AFM images of Shewanella cells on a dolomite surface. (A) A recently divided cell; (B) a rare example of a flagellum that is still attached to a Shewanella cell. 


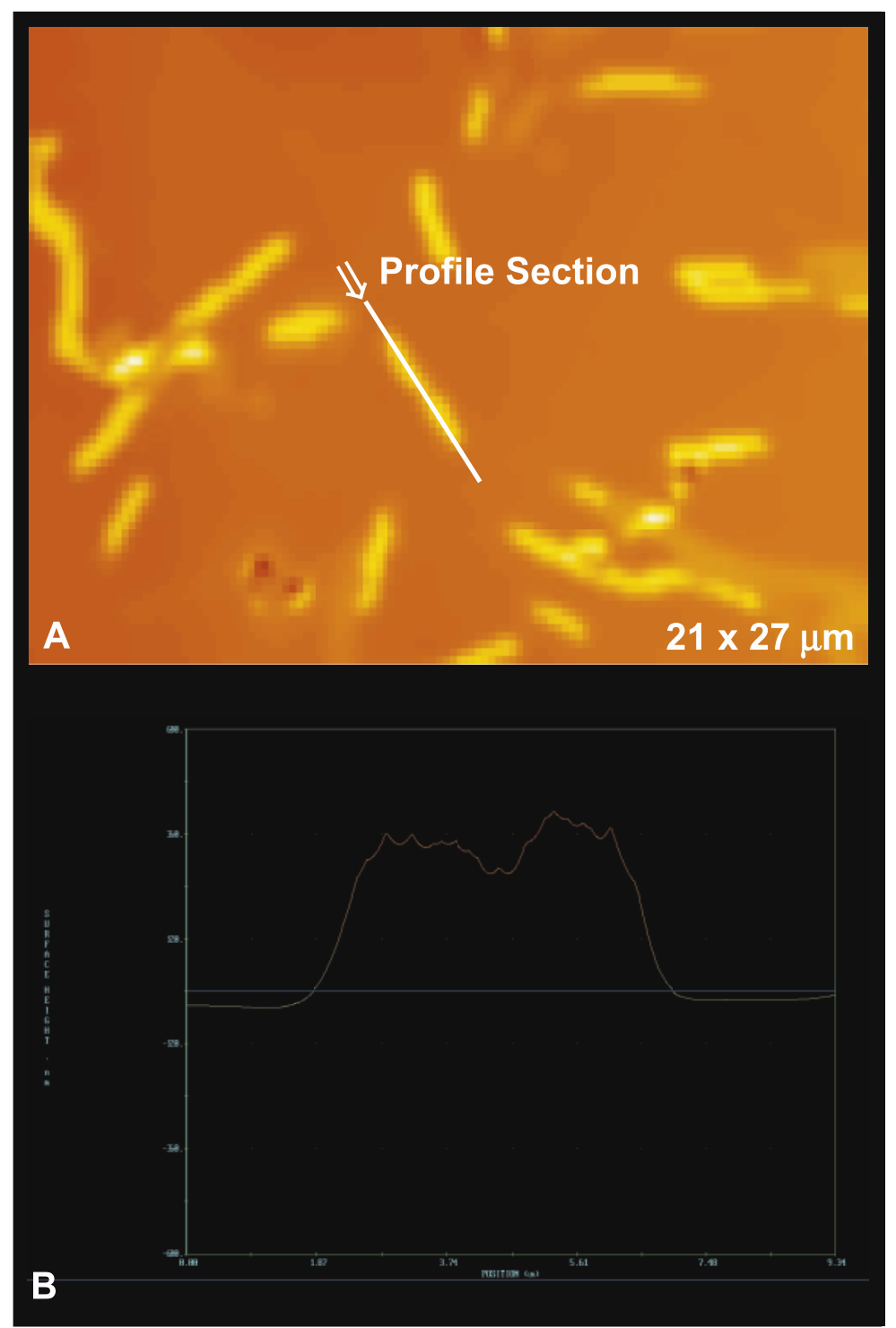

Fig. 9. Cross-section of a recently divided cell on a calcite surface. The individual cells measure 400 and $440 \mathrm{~nm}$ in diameter and 2.5 microns in length. VSI measurements such as these can yield accurate measurements of cell dimensions that compare favorably with those obtained using more common ex situ AFM techniques.

Role of Surface Colonization in Determining Calcite Dissolution Rate

Calcite dissolution rates were measured in the context of microbial attachment by comparing masked portions of the crystal surface to those regions exposed to the experimental test solutions (fig. 14). Table 3 contains the measured surface normal retreats and corresponding dissolution rates for calcite surfaces exposed to both the cell-free control and Shewanella cultures for 35 hours. These measurements indicate that calcite dissolution in the presence of live Shewanella cells was almost 40 percent slower than the dissolution rate ob- 


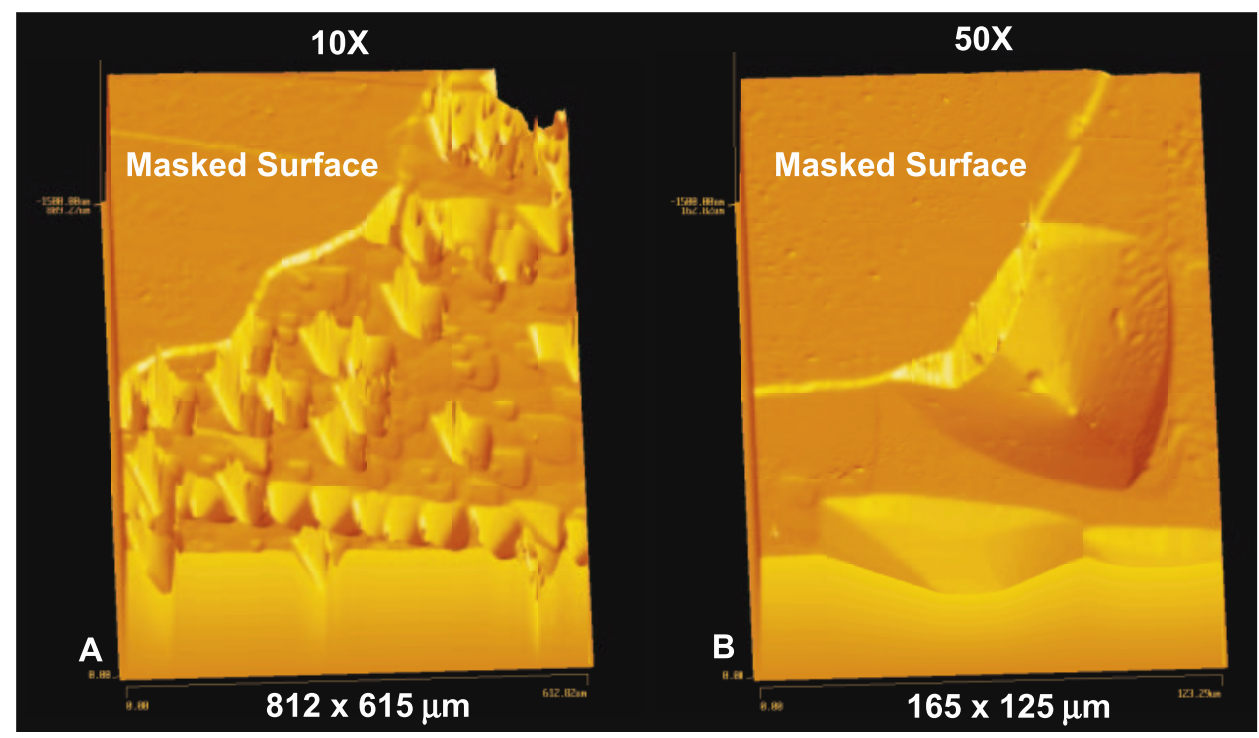

Fig. 10. Images showing the extent of dissolution between masked and unmasked areas of a calcite crystal following 4 hours of reaction in the cell-free control solutions. Both images show portions of the same masked area with the only difference being the magnification of the interferometric objective used. The previously masked portion of the calcite surface is apparent as the smooth (unetched) surface in the upper-left quadrant of the image.

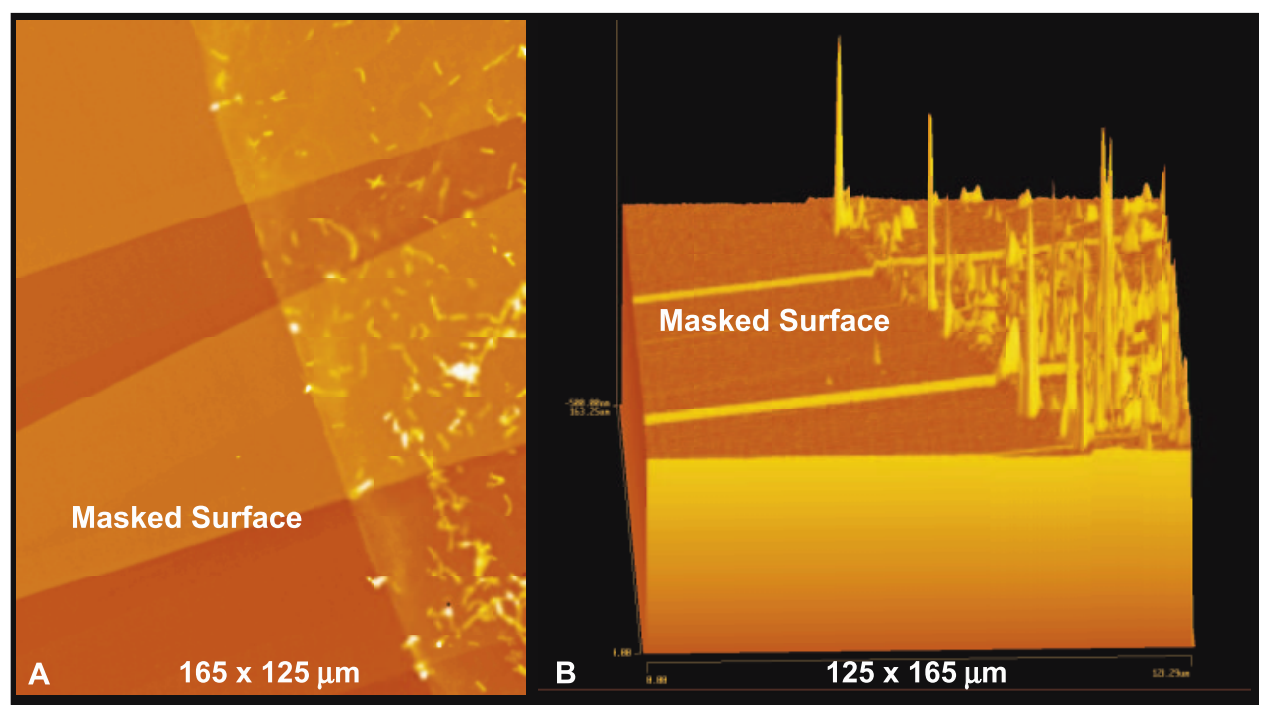

Fig. 11. Images showing the masked and unmasked regions of a dolomite crystal surface following 4 hours of exposure to Shewanella cells. These VSI images reveal that no dolomite dissolution occurred during the reaction period. Instead, a number of Shewanella cells have deposited on the surface along with a thin organic film. The unreacted surface (previously masked) is apparent as the smooth surface on the left side of these images. 


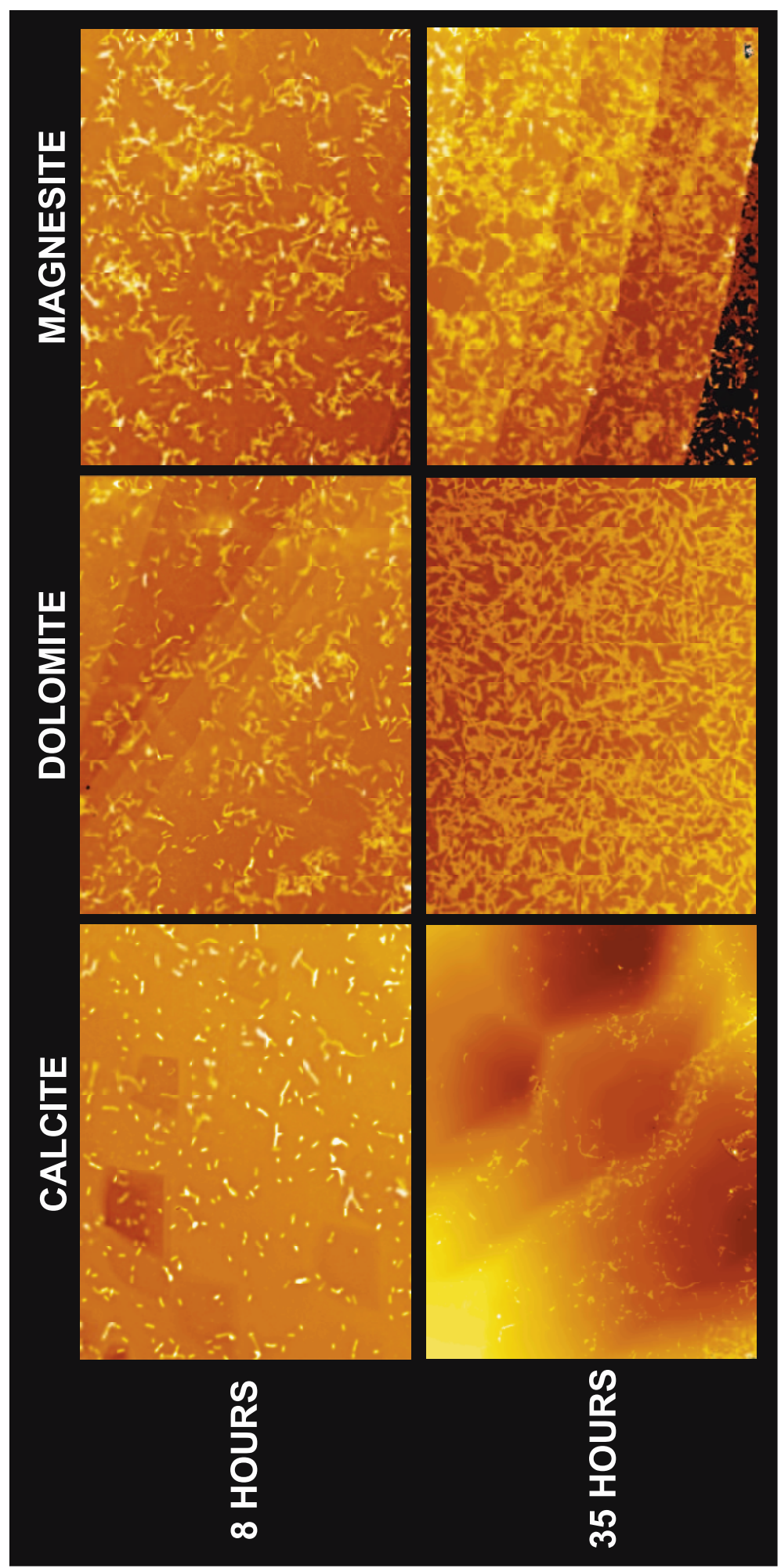

$\odot . \breve{\Xi}$

颉

o

区欠

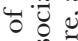

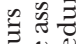

¿

10 峞

उ $\vec{\circ}$.

ส $:$

$\infty$ 管

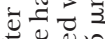

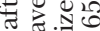

o $=\overline{7}$

可

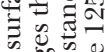

so

क.

50.

छ. …

讨

可

势

읭

응

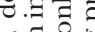

ن

다의

త 0

ธิ

z

$\exists \Xi$

을

응

8 용.

0.0

컵흥

के

$\Xi 0$

呵

충

के

$\exists$.

.

过 뭉

एँ

Es

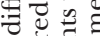

so $z$

हैं

政

की

\% :

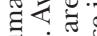

की

$>$ 政

จ

bi

응 


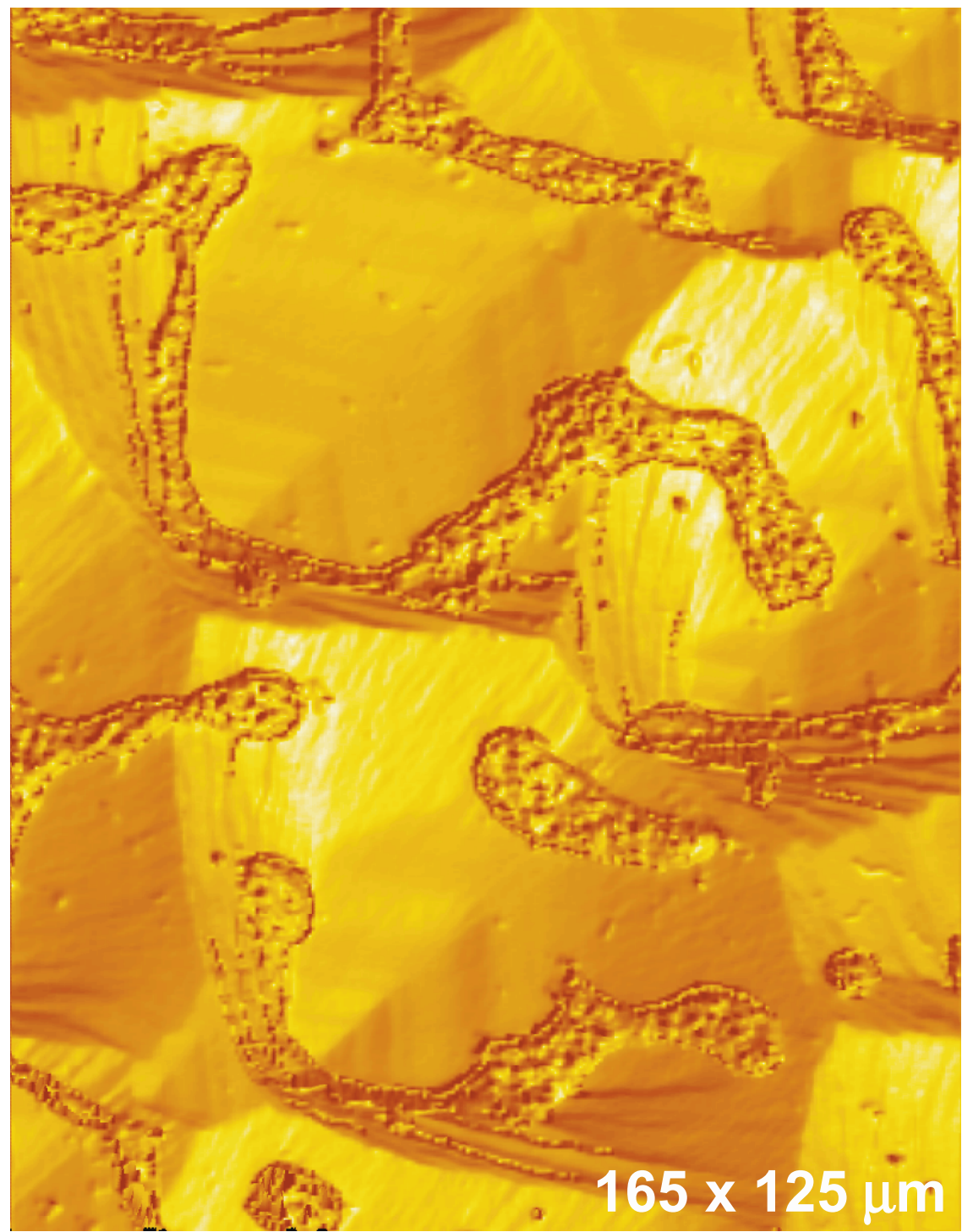

Fig. 13. VSI image of Shewanella surface colonization on the calcite surface after 35 hours. The majority of cells were found to occupy the rims of large etch pits, indicating that microbial attachment may be less favorable near dissolution centers where the surface is most dynamic.

served for the cell-free control solutions. This difference in reaction rate is easily visualized by comparing the masked surfaces to the reacted surfaces in the 3D models shown in figure 14. Insight into the mechanism by which the Shewanella cultures retarded calcite dissolution may be gained by looking at the results for the heat-killed Shewanella control solutions given in table 3 . The measured calcite dissolution rate in solutions containing heat-killed Shewanella cells was similar to the rate measured for the cell-free control. Since the heat-killed cells were not found to attach to the surface, it seems that the measured inhibition of calcite dissolution in the presence of live 


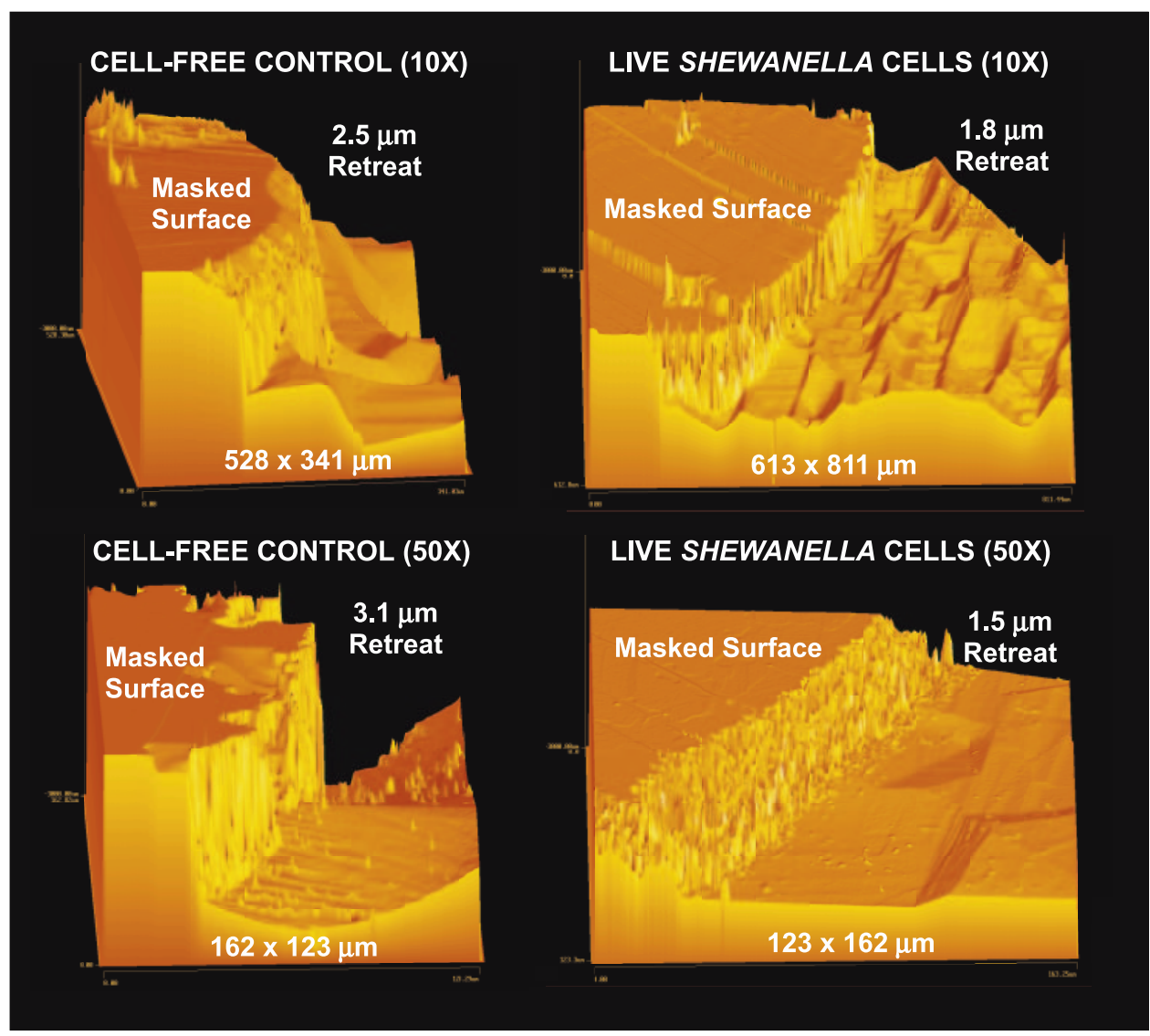

Fig. 14. VSI data of calcite dissolution relative to masked portions of the crystal surface after 35 hours of exposure to cell-free controls and Shewanella cell cultures. 10X and 50X images of the same masked region are shown for comparison. Average measurements of calcite dissolution for the two systems are given in table 3. Here the unreacted portions of the surface occupy the left side of the images.

Shewanella cells resulted from the physical attachment of cells to the surface. This attachment may have slowed calcite dissolution by interfering with the development of etch pits on the crystal surface, as has been previously described by Lüttge and Conrad (2004).

TABLE 3

Calcite Dissolution Measurements After 35 Hours

\begin{tabular}{|c|c|c|}
\hline & $\begin{array}{c}\text { Surface Normal } \\
\text { Retreat }(\mu \mathrm{m})\end{array}$ & $\begin{array}{c}\text { Global Dissolution } \\
\text { Rate }\left(\mathbf{m o l}^{\circ} \mathbf{c m}^{-2} \mathbf{s}^{-1}\right)\end{array}$ \\
\hline Cell-Free Control & 2.83 & $6.1 \times 10^{-11}$ \\
\hline Heat-Killed Cells & 2.71 & $5.8 \times 10^{-11}$ \\
\hline Shewanella Culture & 1.64 & $3.5 \times 10^{-11}$ \\
\hline
\end{tabular}

Global dissolution rates were calculated using a calcite molar volume of $36.93 \mathrm{~cm}^{3} / \mathrm{mol}$. 


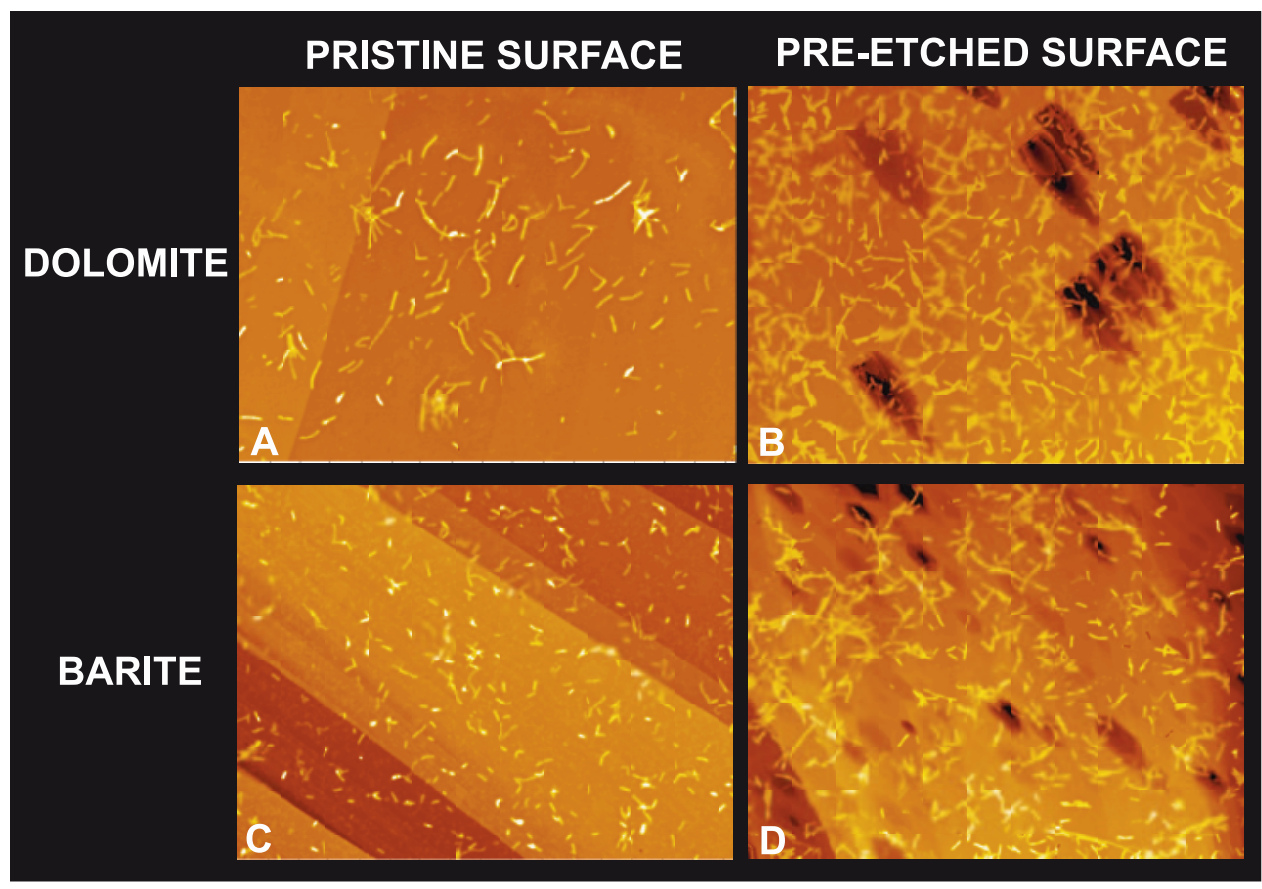

Fig. 15. VSI images of surface colonization on barite and dolomite surfaces after 4 hours. Attached cell density was significantly higher on the pre-etched surfaces than on the pristine cleavages surfaces. Average measurements of attached cell densities are given in table 2. (All images are $125 \times 165 \mu \mathrm{m}$ ).

\section{Role of Mineral-Surface Topography in Determining Surface Colonization}

The role of mineral-surface microtopography in determining cell attachment was tested by exposing pre-etched dolomite and barite crystals to Shewanella cultures and comparing the measured surface cell densities to those of pristine cleavage surfaces exposed to the same solutions. Dolomite and barite surfaces were chosen due to their slow dissolution kinetics relative to the studied exposure times, so that the effect of mineral-surface microtopography on cell attachment could be isolated. It was immediately obvious after short exposure periods that attached cell densities were much greater on the pre-etched surfaces than the pristine cleavage surfaces (fig. 15). Table 2 gives average measurements of cell density for several crystals and indicates that pre-etching resulted in a 2.5 to 5 -fold increase in cell attachment during the 4 hour exposure period. While it appears from VSI imaging alone that cell attachment is uniform across the pre-etched surfaces while etch pit density is not, higher resolution AFM images (fig. 16) of dolomite and barite surfaces revealed the presence of additional dissolution features including smaller etch pits that were below the lateral resolution limits of VSI. These microtopographical features facilitated widespread surface colonization (fig. 17) over much shorter time periods than was required for similar microbial attachment to occur on pristine cleavage surfaces. This result contrasts sharply with observations of the actively dissolving calcite surface, where the presence of etch pits was correlated with lower attached cell density. This observational disparity provides further evidence that surface dynamics plays a definitive role in microbial attachment. 


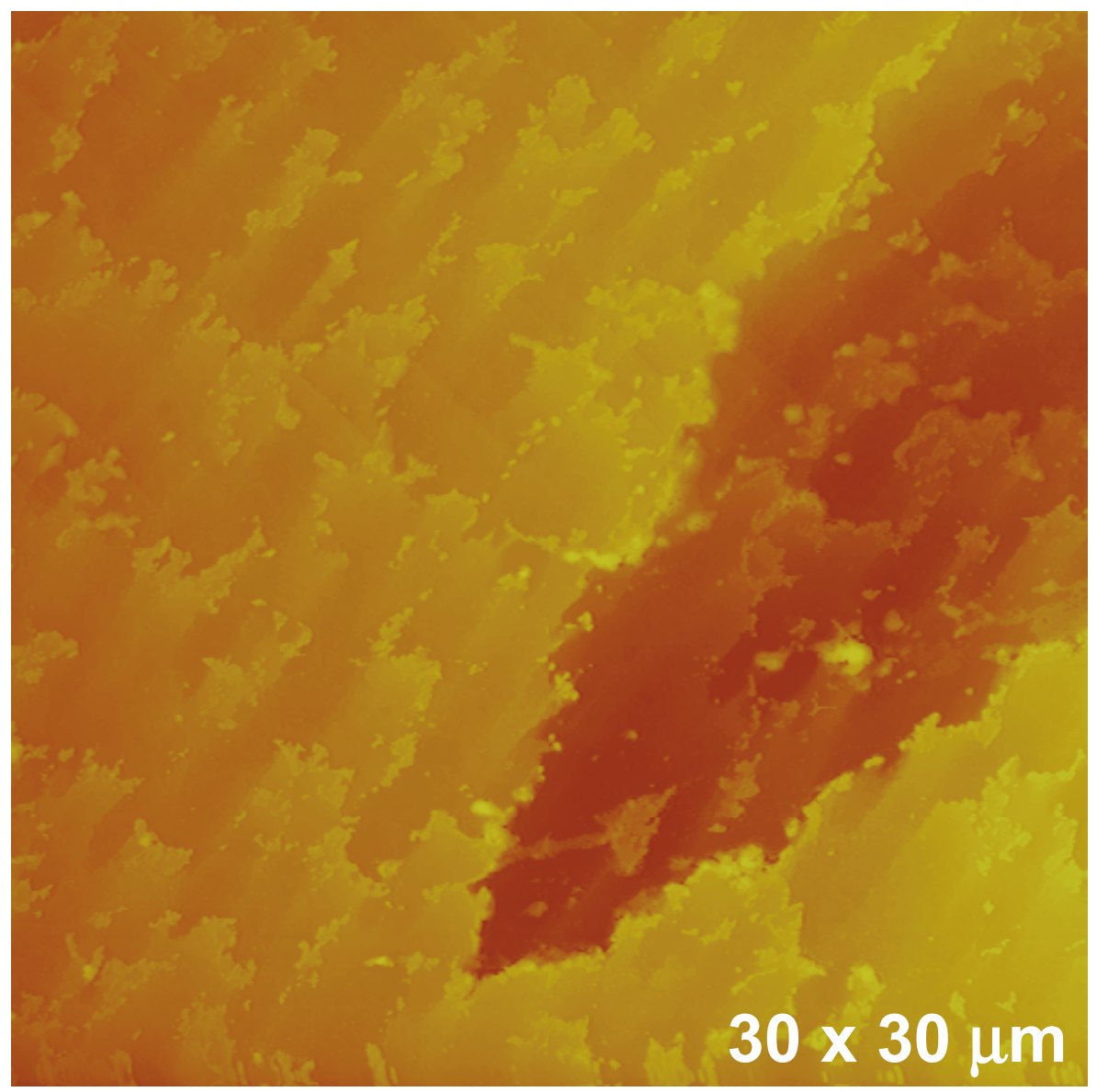

Fig. 16. AFM image of pre-etched dolomite surface revealing extremely rough surface steps that are not observable using VSI.

\section{SUMMARY AND CONCLUSIONS}

Vertical scanning interferometry (VSI) has previously been shown to be extremely useful for making quantitative measurements of inorganic mineral-surface reactions. Here we establish VSI as a powerful tool for quantifying surface reaction rates in the context of microbial surface colonization. Additionally, VSI was shown to be capable of accurately measuring attached cell dimensions and biofilm thicknesses relative to a masked surface. The noninvasive imaging characteristic of VSI, along with fast data acquisition, a large field of view, and large vertical scan range, makes VSI a strong complement to the in situ high-resolution imaging capabilities of atomic force microscopy (AFM). The combination of these two quantitative imaging techniques is wellpositioned to provide the critical information needed to resolve microbe-mineral interactions across multiple length-scales. The power of these techniques would be further amplified when used in conjunction with in situ optical techniques, such as confocal laser scanning microscopy (CLSM), that use fluorescent probes to monitor chemical and physiological aspects of biofilms.

In this study, AFM and VSI were used in synergistic fashion to achieve a beginning understanding of the interplay between mineral-surface dynamics and microbial 


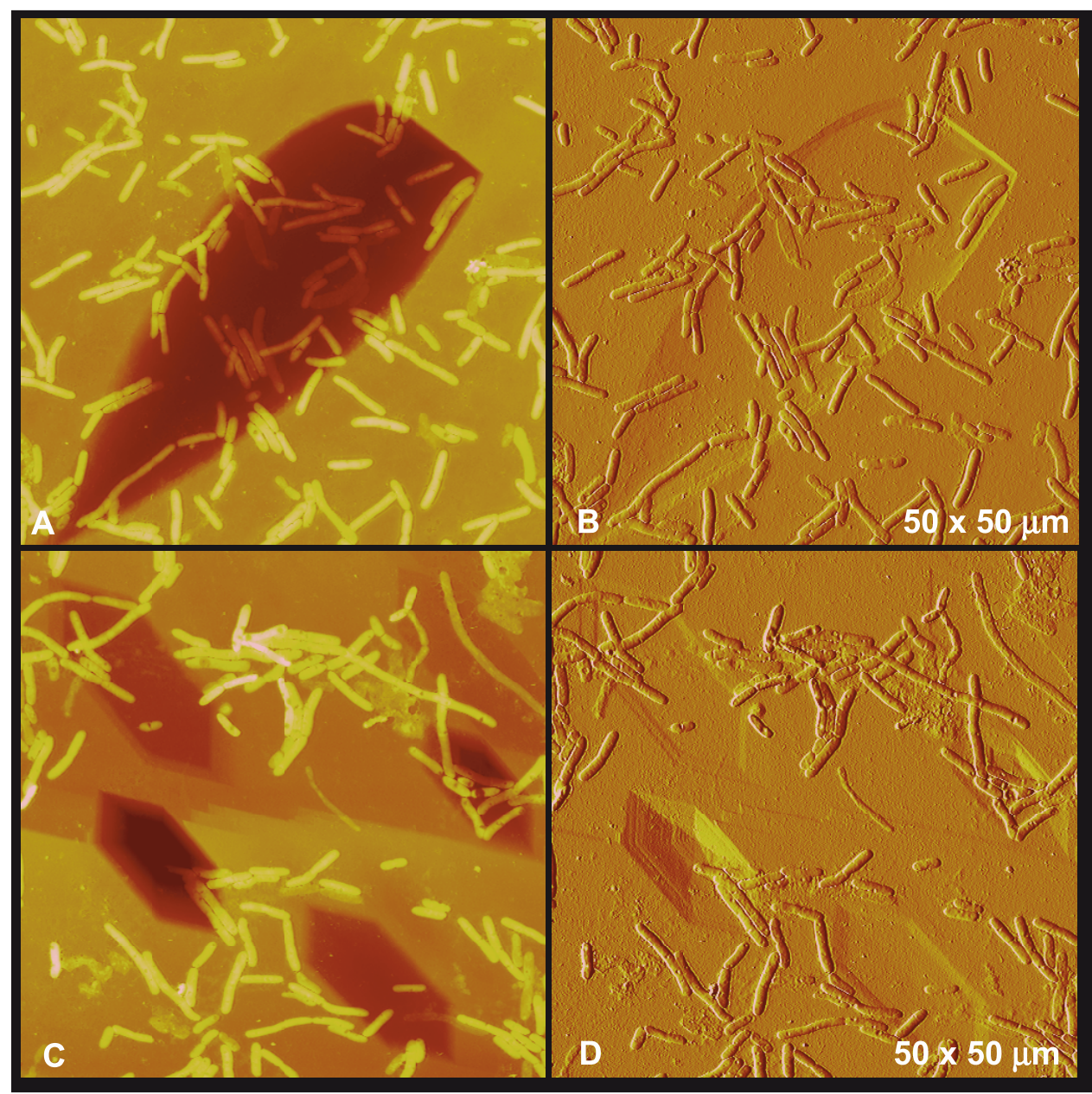

Fig. 17. AFM images of cell attachment on pre-etched dolomite and barite surfaces. Dissolution features like those shown in figure 16 are not visible in these images because of the much greater vertical scale employed to accommodate both bacterial cells and surface features (A) height image of dolomite surface; (B) corresponding deflection (amplitude) plot; (C) height image of barite surface; (D) corresponding deflection (amplitude) plot.

attachment. Our results indicate that when the dissolution rate of the surface is comparable to the rate of surface colonization, surface dynamics may be a significant factor in determining cell attachment. This was found to be the case for calcite where significant surface retreat resulted in reduced Shewanella surface colonization. In further support of this finding, the most dynamic areas of the surface (etch pits) were found to provide additional local barriers to cell attachment. However, the cells that did attach to the calcite surface affected surface dynamics by reducing the overall far from equilibrium dissolution rate. In contrast to the findings for calcite, dissolution features on the slower-dissolving dolomite and barite surfaces actually resulted in faster surface colonization rates by providing energetically favorable sites for cell attachment. This complicated relationship between surface colonization and mineral-surface development reinforces the central theme of biogeochemistry that the evolution of geological surfaces and biological systems are intertwined. However, the significance of these 
relationships to biogeochemical and engineered systems requires further investigation.

\section{ACKNOWLEDGMENTS}

The authors wish to thank Kenneth Nealson and Randa Abboud (University of Southern California) for generously providing the Shewanella cultures used in this study. The authors also gratefully acknowledge support for this study from the Department of Energy (grant\#DE-FG03-02ER63427), and the Nanoscale Science and Engineering Initiative of the National Science Foundation under NSF Award Number EEC-0118007 (to A. Lüttge). In addition, the authors would like to thank Catherine Skinner, Javiera Cervini-Silva, and Rob Rye, for extremely helpful and insightful reviews of this manuscript.

\section{REFERENCES}

Arnold, R. G., DiChristina, T. J., and Hoffman, M. R., 1988, Reductive dissolution of Fe(III) oxides by Pseudomonas sp. 200: Biotechnology and Bioengineering, v. 32, p. 1081-1096.

Arvidson, R. S., Ertan, I. E., Amonette, J. E., and Lüttge, A., 2003, Variation in Calcite Dissolution Rates: A Fundamental Problem?: Geochimica et Cosmochimica Acta, v. 67, p. 1623-1634.

Arvidson, R. S., Beig, M. S., and Lüttge, A., 2004, Single-crystal plagioclase feldspar dissolution rates measured by vertical scanning interferometry: American Mineralogist, v. 89, p. 51-56.

Bakke, R., Characklis, W. G., Turakhia, M. H., and Yeh, A., 1990, Modeling a Monopopulation Biofilm System: Pseudomonas Aeruginosa, in Characklis, W. G., and Marshall, K. C., editors, Biofilms: New York, John Wiley and Sons, Inc., p. 487-520.

Banfield, J. F., Welch, S. A., and Edwards, K. J., 1998, Microbes as Geochemical Agents: The Geochemical News, No. 96, p. 11-17.

Barker, W. W., Welch, S. A., and Banfield, J. F., 1997, Biogeochemistry of silicate mineral weathering, in Banfield, J. F., and Nealson, K. H., editors, Geomicrobiology: Interactions between microbes and minerals: Mineralogical Society of America Reviews in Mineralogy, v. 35, p. 391-428.

Bennett, P. C., and Hiebert, F. K., 1992, Microbial mediation of silicate diagenesis in organic-rich natural waters, in Kharaka, Y. K., and Maest, A. S., editors, Water-Rock Interaction: Rotterdam, AA Balkema, p. 267-270.

Bennett, P. C., Hiebert, F. K., and Choi, W. J., 1996, Microbial colonization and weathering of silicates in a petroleum-contaminated aquifer: Chemical Geology, v. 132, p. 45-53.

Boyd, R. D., Verran, J., Jones, M. V., and Bhakoo, M., 2002, Use of the Atomic Force Microscope to Determine the Effect of Substratum Surface Topography on Bacterial Adhesion: Langmuir, v. 18, p. 2343-2346.

Characklis, W. G., 1990, Microbial Fouling, in Characklis, W. G., and Marshall, K. C., editors, Biofilms: New York, John Wiley and Sons, Inc., p. 523-584.

Davis, K. J., Dove, P. M., and De Yoreo, J. J., 2000, The role of $\mathrm{Mg}^{2+}$ as an impurity in calcite growth: Science, v. 290, p. 1134-1137.

Davis, K. J., Dove, P. M., Wasylenki, L. E., and De Yoreo, J. J., 2004, Morphological consequences of differential $\mathrm{Mg}^{2+}$ incorporation at structurally distinct steps on calcite: American Mineralogist, v. 89, p. 714-720.

Dawson, M. P., Humphrey, B., and Marshall, K. C., 1981, Adhesion: A tactic in the survival strategy of a marine vibrio during starvation: Current Microbiology, v. 6, p. 195-99.

DiChristina, T. J., and DeLong, E. F., 1994, Isolation of anaerobic respiratory mutants of Shewanella putrefaciens and genetic analysis of mutants deficient in anaerobic growth on $\mathrm{Fe}^{3+}$ : Journal of Bacteriology, v. 176, p. 1468-1474.

Ehrlich, H. L., 1998, Geomicrobiology: its significance for geology: Earth-Science Reviews, v. 45, p. 45-60. 1999, Microbes as Geologic Agents: Their Role in Mineral Formation: Geomicrobiology Journal, v. 16, p. 135-153.

Flemming, H. C., and Schaule, G., 1996, Biofouling, in Heitz, E., Flemming, H. C., and Sand, W., editors, Microbially Influenced Corrosion of Materials: Scientific and Engineering Aspects: Berlin, Springer, p. $39-54$.

Fletcher, M., 1996, Bacterial Attachment in Aquatic Environments: A Diversity of Surfaces and Adhesion Strategies, in Fletcher, M., editor, Bacterial Adhesion: Molecular and Ecological Diversity: New York, John Wiley and Sons, Inc., p. 1-24.

Fletcher, M., and Murphy, E., 2001, Transport of Microorganisms in the Subsurface: The Role of Attachment and Colonization of Particle Surfaces, in, Fredrickson, J. K., and Fletcher, M., editors, Subsurface Microbiology and Biogeochemistry: New York, John Wiley and Sons, Inc., p. 39-68.

Fortin, D., Ferris, F. G., and Beveridge, T. J., 1997, Surface-Mediated Mineral Development by Bacteria, in Banfield, J. F., and Nealson, K. H., editors, Geomicrobiology: Interactions between microbes and minerals: Mineralogical Society of America Reviews in Mineralogy, v. 35, p. 161-177.

Geesey, G. G., and Bryers, J. D., 2000, Biofouling of Engineered Materials and Systems, in Bryers, J. D., editor, Biofilms II: Process Analysis and Applications: New York, John Wiley and Sons, Inc., p. 237-280. 
Geesey, G. G., Beech, I., Bremer, P. J., Webster, B. J. and Wells, D. B., 2000, Biocorrosion, in Bryers, J. D., editor, Biofilms II: Process Analysis and Applications: New York, John Wiley and Sons, Inc., p. 281-326.

Grasso, B. F., Smets, K. A., Strevett, B. D., Machinist, C. J., Van Oss, R. F., Giese, and Wu, W., 1996, Impact of Physiological State on Surface Thermodynamics and Adhesion of Pseudomonas aeruginosa: Environmental Science and Technology, v. 30, p. 3604-3608.

Gratz, A. J., Hillner, P. E., and Hansma, P. K., 1993, Step dynamics and spiral growth on calcite: Geochimica et Cosmochimica Acta, v. 57, p. 491-495.

Hamilton, W. A., 1995, Biofilms and Microbially Influenced Corrosion, in Lappin-Scott, H. M., and Costerton, J. W., editors, Microbial Biofilms: New York, Cambridge University Press, p. 171-182.

Hiebert, F. K., and Bennett, P. C., 1992, Microbial control of silicate weathering in organic-rich ground water: Science, v. 258, p. 278-281.

Higgins, S. R., Bosbach, D., Eggleston, C. M., and Knauss, K. G., 2000, Kink Dynamics and Step Growth on Barium Sulfate (001): A Hydrothermal Scanning Probe Microscopy Study: Journal of Physical Chemistry B, v. 104, p. $6978-6982$.

Jordan, G., and Rammensee, W., 1998, Dissolution rates of calcite (1014) obtained by scanning force microscopy: Microtopography-based dissolution kinetics on surface with anisotropic step velocities: Geochimica et Cosmochimica Acta, v. 62, p. 941-947.

Kjelleberg, S., and Hermansson, M., 1984, Starvation-induced effects on bacterial surface characteristics: Applied Environtmental Microbiology, v. 48, p. 497-503.

Korber, D. R., Lawrence, J. R., Lappin-Scott, H. M., and Costerton, J. W., 1995, Growth of Microorganisms on Surfaces, in Lappin-Scott, H. M., and Costerton, J. W., editors, Microbial Biofilms: New York, Cambridge University Press, p. 15-45.

Lasaga, A. C., and Lüttge, A., 2001, Variation of Crystal Dissolution Rate Based on a Dissolution Stepwave Model: Science, v. 291, p. 2400-2404. 2003, A model for crystal dissolution: European Journal of Mineralogy, v. 15, p. 603-615.

Lens, P., Moran, A. P., Mahony, T., Stoodley, P., and O'Flaherty, V., 2003, Biofilms in Medicine, Industry and Environmental Biotechnology: Characteristics, Analysis and Control: Cornwall, IWA Publishing, $610 \mathrm{p}$.

Liang, Y., Baer, D. R., McCoy, J. M., Amonette, J. E., and LaFemina, J. P., 1996, Dissolution kinetics at the calcite-water interface: Geochimica et Cosmochimica Acta, v. 60, p. 4883-4887.

Little, B. J., Wagner, P. A., Characklis, W. G., and Lee, W., 1990, Microbial Corrosion, in Characklis, W. G., and Marshall, K. C., editors, Biofilms: New York, John Wiley and Sons, Inc., p. 635-670.

Little, B. J., Wagner, P. A., and Lewandowski, Z., 1997, Spatial Relationships Between Bacteria and Mineral Surfaces, in Banfield, J. F., and Nealson, K. H., editors, Geomicrobiology: Interactions between microbes and minerals: Mineralogical Society of America Reviews in Mineralogy, v. 35, p. 123-155.

Lovley, D. R., and Blunt-Harris, E. L., 1999, Role of Humic-Bound Iron as an Electron Transfer Agent in Dissimilatory Fe(III) Reduction: Applied and Environmental Microbiology, v. 65, p. 4252-4254.

Lovley, D. R., and Phillips, E. J. P., 1988, Novel mode of microbial energy-metabolism: organic-carbon oxidation coupled to dissimilatory reduction of iron or manganese: Applied and Environmental Microbiology, v. 54, p. 1472-1480.

Lovley, D. R., Coates, J. D., Blunt-Harris, E. L., Phillips, E. J. P., and Woodward, J. C., 1996, Humic substances as electron acceptors for microbial respiration: Nature, v. 382, p. 445-448.

Lower, S. K., Tadanier, C. J., and Hochella, Jr., M. F., 2000, Measuring interfacial and adhesion forces between bacteria and mineral surfaces with biological force microscopy: Geochimica et Cosmochimica Acta, v. 64, p. 3133-3139.

— 2001a, Dynamics of the Mineral-Microbe Interface: Use of Biological Force Microscopy in Biogeochemistry and Geomicrobiology: Geomicrobiology Journal, v. 18, p. 63-76.

Lower, S. K., Hochella, Jr., M. F., and Beveridge, T. J., 2001b, Bacterial recognition of mineral surfaces: nanoscale interactions between Shewanella and $\alpha$-FeOOH: Science, v. 292, p. 1360-1363.

Lüttge, A., and Conrad, P. G., 2004, Direct Observation of Microbial Inhibition of Calcite Dissolution: Applied and Environmental Microbiology, v. 70 (3), p. 1627-1632.

Lüttge, A., Bolton, E. W., and Lasaga, A. C., 1999, An Interferometric Study of the Dissolution Kinetics of Anorthite: The Role of Reactive Surface Area: American Journal of Science, v. 299, p. 652-678.

Lüttge, A., Winkler, U., and Lasaga, A. C., 2003, Interferometric study of dolomite dissolution: A new conceptual model for mineral dissolution: Geochimica et Cosmochimica Acta, v. 67, p. 1099-1116.

Marshall, K. C., 1996, Adhesion as a strategy for access to nutrients, in Fletcher, M., editor, Bacterial Adhesion: New York, John Wiley and Sons, Inc., p. 59-87.

Mills, A. L., and Powelson, D. K., 1996, Bacterial Interactions with Surfaces in Soils, in Fletcher, M., editor, Bacterial Adhesion: Molecular and Ecological Diversity: New York, John Wiley and Sons, Inc., p. $25-58$.

Nealson, K. H., and Myers, C. R., 1992, Microbial reduction of manganese and iron: New approaches to carbon cycling: Applied and Environmental Microbiology, v. 58, p. 439-443.

Newman, D. K., and Kolter, R., 2000, A role for excreted quinones in extracellular electron transfer: Nature, v. 405 , p. $94-97$.

Pina, C. M., Becker, U., Risthaus, P., Bosbach, D., and Putnis, A., 1998, Molecular-scale mechanisms of crystal growth in barite: Nature, v. 395, p. 483-486.

Prince, A., 1996, Pseudomonas Aeruginosa: Versatile Attachment Mechanisms, in Fletcher, M., editor, Bacterial Adhesion: Molecular and Ecological Diversity: New York, John Wiley and Sons, Inc., p. 183-200.

Risthaus, P., Bosbach, D., Becker, U., and Putnis, A., 2001, Barite scale formation and dissolution at high ionic strength studied with atomic force microscopy: Colloids and Surfaces A: Physiochemical and Engineering Aspects, v. 191, p. 201-214.

Rosso, K. M., Zachara, J. M., Fredrickson, J. K., Gorby, Y. A., and Smith, S. C., 2003, Nonlocal bacterial electron transfer to hematite surfaces: Geochimica et Cosmochimica Acta, v. 67, p. 1081-1087. 
Scheuerman, T. R., Camper, A. K., and Hamilton, M. A., 1998, Effects of Substratum Topography on Bacterial Adhesion: Journal of Colloid and Interface Science, v. 208, p. 23-33.

Teng, H. H., Dove, P. M., Orme, C. A., and De Yoreo, J. J., 1998, Thermodynamics of Calcite Growth: Baseline for Understanding Biomineral Formation: Science, v. 282, p. 724-727.

Teng, H. H., Dove, P. M., and De Yoreo, J. J., 2000, Kinetics of calcite growth: surface processes and relationships to macroscopic rate laws: Geochimica et Cosmochimica Acta, v. 64, p. 2255-2266.

Tiedje, J. M., 2002, Shewanella - the environmentally versatile genome: Nature Biotechnology, v. 20, 1093-1094.

Videla, H. A., 1996, Manual of Biocorrosion: Boca Raton, CRC Lewis Publishers, 273 p.

Wagner, D., Fischer, W. R., Paradies, H. H., and von Franqué, O., 1996, Microbiologically Influenced Corrosion in Copper Potable Water Installations, in Heitz, E., Flemming, H. C., and Sand, W., editors, Microbially Influenced Corrosion of Materials: Scientific and Engineering Aspects: Berlin, Springer, p. 259-269

ZoBell, C. E., 1943, The effect of solid surfaces upon bacterial activity: Journal of Bacteriology, v. 46, p. $39-56$. 